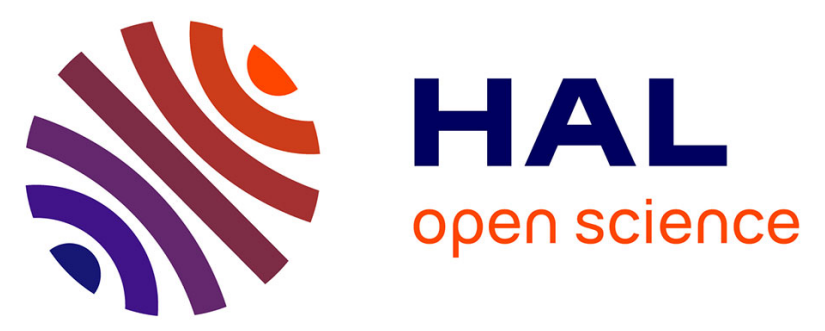

\title{
Xitle Volcano Geoheritage, Mexico City: Raising Awareness of Natural Hazards and Environmental Sustainability in Active Volcanic Areas
}

Marie-Noëlle Guilbaud, María del Pilar Ortega-Larrocea, Silke Cram, Benjamin van Wyk de Vries

\section{To cite this version:}

Marie-Noëlle Guilbaud, María del Pilar Ortega-Larrocea, Silke Cram, Benjamin van Wyk de Vries. Xitle Volcano Geoheritage, Mexico City: Raising Awareness of Natural Hazards and Environmental Sustainability in Active Volcanic Areas. Geoheritage, 2021, 13 (6), 10.1007/s12371-020-00525-9 . hal-03118765

\section{HAL Id: hal-03118765 https://hal.science/hal-03118765}

Submitted on 22 Jan 2021

HAL is a multi-disciplinary open access archive for the deposit and dissemination of scientific research documents, whether they are published or not. The documents may come from teaching and research institutions in France or abroad, or from public or private research centers.
L'archive ouverte pluridisciplinaire $\mathbf{H A L}$, est destinée au dépôt et à la diffusion de documents scientifiques de niveau recherche, publiés ou non, émanant des établissements d'enseignement et de recherche français ou étrangers, des laboratoires publics ou privés. 
1 Xitle Volcano Geoheritage, Mexico City: Raising awareness of natural hazards and

2 environmental sustainability in active volcanic areas.

4 Marie-Noëlle Guilbaud ${ }^{1}$, María del Pilar Ortega-Larrocea ${ }^{2}$, Silke $\mathrm{Cram}^{3}$, Benjamin van Wyk

5 de Vries $^{4}$

$6{ }^{1}$ Departamento de Vulcanología, Instituto de Geofísica, UNAM, Mexico.

7 marie@igeofisica.unam.mx; marienoelle.guilbaud@gmail.com, ORCID 0000-0002-7380-

$8 \quad 4419$

$9 \quad{ }^{2}$ Departamento de Ciencias Ambientales y del Suelo, Instituto de Geología, UNAM, Mexico.

$10{ }^{3}$ Instituto de Geografía, UNAM, Mexico

$11{ }^{4}$ Laboratoire Magmas et Volcans, Observatoire du Physique du Globe de Clermont,

12 Université Clermont Auvergne, IRD, UMR6524-CNRS, Aubière, France

\section{Abstract (250 words)}

16 The conservation of geosites in a region can foster its sustainability and develop geotourism.

17 These geosites provide geoeducation, raise people's awareness on natural hazards and

18 increase their resilience. Low-income cities located in tectonically active areas combine high

19 geohazards with high vulnerability and low sustainability. Geosites in these cities should be

20 a tool to decrease people's vulnerability and foster sustainable development. Mexico City is

21 an ideal case study for its environmental and social issues and its setting in an active 
22 continental volcanic arc. The 1,700 yrs-old Xitle volcano, located in the city's SW corner, is

23 a small scoria cone that erupted once, feeding an extensive lava field on which $>600,000$

24 people now live. The lavas are very well exposed due to thin soils and extensive quarrying.

25 The Xitle lavas covered the first urban center in the Mexico basin, except for the main

26 pyramid that has become a major archeological site. The cone and lavas have significant

27 geodiversity, sustaining a unique and biodiverse ecosystem. The country's largest university

28 preserves the lavas in an ecological reserve. We describe four exceptional geosites, assess

29 their values, and discuss their relevance for addressing issues such as nature preservation,

30 environmental sustainability, social inequalities, and natural hazards. The Xitle volcano

31 provides a wide range of benefits for the city that are nonetheless unknown to its inhabitants.

32 We describe ongoing initiatives to disseminate such information, such as the Geopedregal

33 site, and propose ways that this heritage could be further protected and used by the city in a

34 sustainable way.

\section{Keywords (4-6)}

37 Volcanic geosites, geoeducation, geodiversity, geohazards, sustainability

39 Declarations

$41 \quad$ Funding

42 MNG completed this manuscript during a sabatical year at the Laboratoire Magmas et

43 Volcans (France) sponsored by a grant from the Programa de Apoyos para la Superación del

44 Personal Académico de la Universidad Nacional Autonoma de Mexico, UNAM (PASPA- 
45 DGAPA-UNAM). This project is part of the broader, international UNESCO IGCP 692

46 "Geoheritage for Geohazard Resilience" project (www.geopoderes.com). The Geopedregal

47 site received funds from UNAM-DGAPA-PAPIME PE108915, PAPIIT IT101812,

48 IV200117, and the Institutes of Geology and Geography at UNAM. Benjamin van Wyk de

49 Vries acknowledges support from the Agence Nationale de la Recherche of the French

50 government, through the programme 'Investissements d'Avenir' (16-IDEX-0001 CAP 20-

51 25), including the project 'Resilience through Geoheritage and Geotourism'.

\section{Conflicts of interest/Competing interests}

54 Not applicable

\section{Availably of data and material}

57 Not applicable

\section{Code availability}

60 Not applicable

\section{Authors' contribution}

63 MNG wrote the manuscript and made the figures. PO described biological elements and SC

64 pedological elements at specific sites. BW revised the English and made valuable suggestions

65 for the discussion. The four authors discussed the scientific, educational and touristic values

66 of the sites and the relevance of Xitle volcano for addressing multiple issues of the city. 


\section{Acknowledgments}

69 Students of the workshop "Restauración de pedregales y valoración de servicios

70 ecosistémicos en Ciudad Universitaria" took some pictures in the Geopedregal site and

71 contributed to its description (Mariel Wall, Adriana Gómez, Nadia Martínez, Laura Valadez).

72 Nestor Tunal and Emanuel Zeno did the levelling survey in the Geopedregal site that

73 provided a topographical model presented in this paper. Several people helped in the field,

74 including Victor Peña and Helena Cotler at the Xitle cone, and Nahir Molina Guadarrama at

75 Cuicuilco. Claus Siebe raised the main author's early interest on Xitle and participated to

76 some field excursions. Felipe D. Guzmán took photographs at the Pumas Quarry site. The

77 ICA Foundation and A. Lenz contributed aerial photographs. The editor and two anonymous

78 reviewers provided valuable comments and suggestions that improved the manuscript.

80 Text

\section{Introduction}

84 The preservation, recuperation and valuing of natural sites in cities is a way to promote nature

85 conservation, environmental sustainability and human wellbeing (e.g., Hough 2004; Jim

86 2004; van den Berg et al. 2010). The importance of biological elements for attaining these

87 benefits is widely recognized, yet geological elements (such as rocks, landforms, fossils, etc.)

88 are generally not or hardly considered in environmental policies and urban planning (e.g.,

89 Boothroyd and McHenry 2019; Gray 2013; Brilha et al. 2018; Gray 2018; Gordon et al.

90 2018). Accordingly, protected green spaces are relatively common in cities (e.g., Jim 2013; 
91 Zambrano et al. 2019), whereas analogous places for rocks and landforms are rare (Portal

92 and Kerguillec 2018). Construction works continuously expose new outcrops, but these are

93 generally viewed as unaesthetic and a source of danger through falling blocks, hence,

94 exposures are frequently destroyed or covered, losing their potential value (Reynard et al.

95 2017; Vereb et al. 2020). In the long term, the original topography and landscape is altered

96 significantly, alienating people from their local geology, territory and natural setting (e.g.,

97 Reynard et al. 2017; Ticar et al. 2017; Clivaz and Reynard 2018), with potentially disastrous

98 consequences for their environmental wellbeing and their awareness of natural hazards.

99 Geoparks are good examples of how the conservation of remarkable geological

100 elements of a territory (i.e. geoheritage) can be used through education and tourism to

101 promote sustainability (e.g., McKeever and Zouros 2005). These programmes are based on

102 the identification of sites that contain geological elements either with high scientific value

103 (geosites) or with limited scientific value but high touristic and educational potential

104 (geodiversity sites) (Brilha 2016). The conservation and valuing of geosites in cities could

105 help them reach greater environmental sustainability, increase human wellness, as well as

106 develop new sources of revenue through geotourism (Rodrigues et al. 2011; Gorska-

107 Zabielska and Zabielski 2017; Ticar et al. 2017; Reynard et al. 2017). Urban geosites can

108 also enhance knowledge and people's perception of the relationship between urban

109 development, culture, and natural processes (Del Monte et al. 2013; Picar et al. 2016, 2017;

110 Reynard et al. 2017). Such initiatives are particularly relevant in areas with high georisks,

111 because they provide geoeducation and strengthen local communities, improving social

112 awareness and resilience to hazards and reducing disaster risk (Eiser et al. 2012; Fassoulas

113 et al. 2018; Pavlova 2019; Petrosino et al. 2019). Identifying geosites in cities of developing 
114 countries that are located in tectonically-active areas (i.e. close to tectonic plate edges) is

115 crucial because these cities combine multiple geohazards (such as earthquakes, volcanoes,

116 landslides, flooding) with high vulnerability and low sustainability due to a wide range of

117 socio-economic, educational, and political issues (e.g. Hardoy et al. 2013). The metropolis

118 of Mexico City is one of the largest urban areas in the world ( $>20.9$ million inhabitants, Censo

119 de Poblacion y Vivienda 2010, INEGI), with infamous environmental problems (e.g.,

120 Schteingart 1989). Because of its location in a lake basin at the center of an active volcanic

121 arc, the city is exposed to numerous natural hazards including earthquakes, volcanic

122 eruptions, water shortages, subsidence, landslides and flooding (e.g. Siebe and Macias 2006;

123 Aragón-Durand 2007; Mancebo 2007; Ortiz-Zamora and Ortega-Guerrero 2010). Although

124 these hazards affect the society as a whole, poor people living in the city's outskirts are

125 particularly vulnerable (e.g., Mancebo 2007; Eakin et al. 2016).

126 Recent events such as the series of large earthquakes in 2017 have shown that most

127 people in Mexico City lack basic knowledge on geology and natural processes in general,

128 and distrust official information. In contrast, they are particularly susceptible to influence

129 from deformed, inaccurate or false information (fake news) diffused through the internet,

130 which decreases their ability to understand scientifically-validated information and take

131 appropriate measures for their own protection. Scientists lack time to transmit their

132 knowledge at the scale and constancy needed, and the medias often distort their message for

133 their convenience. In this context, geosites could be a tool to improve both sustainability and

134 awareness on geohazards by preserving natural spaces and facilitating continual

135 communication between the science community and society, improving geoeducation and 136 reducing the risk of disasters. 
138 with preserving and developing urban geosites with the remarkable case of the Xitle volcano

139 in SW Mexico City. Xitle is a young volcano that formed on the edge of the Mexico basin

140 by a single, uninterrupted eruption less than 1700 yrs ago (Siebe 2000). Its eruption produced

141 a large lava field that hosts the last remaining natural sites in the southern part of Mexico

142 City, as well as the central campus of Mexico's national university that is a major World

143 Heritage cultural site (Pezzoli 2000; Cano-Santana et al. 2006). Palacio and Guilbaud (2015)

144 identified nine geosites related to the volcano that have high geological, archaeological,

145 cultural and educational relevance. In this paper, we present a more complete, holistic

146 assessment of the geoheritage value of this volcano, by emphasizing its relevance to

147 conservation, education, and research on the global Earth system, including anthropogenic

148 activity. We select and describe in detail four geosites that should be considered a priority

149 for conservation and valuation due to their high values of representativeness, integrity,

150 association with additional values (environmental, archaeological etc), observation

151 conditions and didactic potential. We also name other sites that have lower scientific value

152 but which could be used for local outreach and touristic activities. All these sites are

153 threatened with serious damage due to the densification of the city and the need of new land

154 for housing and educational infrastructure (Pezzoli 2000; Cano-Santana et al. 2006; Aguilar

155 and Santos 2011; Pérez-Galicia and Pérez-Campuzano 2015). The specific goal of this study

156 is to provide the necessary elements to the university and the local authorities to plan specific

157 actions in order to guarantee the preservation and popularization of the Xitle geoheritage,

158 which in turn would help protect the city itself from natural hazards. 
162 Xitle volcano consists of a small scoria cone (140 m high, $500 \mathrm{~m}$ wide) and a large lava field

163 (ca. $80 \mathrm{~km}^{2}$ ) that were produced by a single basaltic eruption less than $1670 \mathrm{yrs}$ ago (Delgado

164 et al. 1998; Siebe 2000). The volcano erupted at $3000 \mathrm{~m}$ asl, on the northern flank of the

165 Sierra Chichinautzin mountain range that borders the south of Mexico Basin (Fig. 1). After

166 an initial explosive phase, the volcano effused lavas that flowed down into, and invaded the

167 southwest part of the Mexico basin, burying most of a pre-hispanic city (Cuicuilco) and

168 reaching the shores of the ancient, now mostly drained, Xochimilco and Texcoco lakes at ca.

$1692250 \mathrm{~m}$ asl, $12 \mathrm{~km}$ from source. The lava field is complex and consists of multiple units

170 indicating a pulsing effusive activity punctuated by minor explosive phases. The large

171 volume erupted $\left(>1 \mathrm{~km}^{3}\right)$ suggests that the eruption lasted a decade or more. The lavas form

172 barren, rocky land with irregular topography that was mostly left un-populated, until the

173 central campus of the National University of Mexico (UNAM) was built in 1948-1952 on the

174 far end of the flow (Fig. 2A, 2B; Carrillo-Trueba 1995; Salas Portugal 2006). At about the

175 same time, the "Jardines del Pedregal" (gardens of the rocky place), an exclusive residential

176 area just west of UNAM, was constructed under the guidance of world-renown architects and

177 artists (e.g., Rivera 1945; Pérez-Méndez 2007). The urbanization of the lava continued

178 southwards and towards the volcano, with the construction of housing and infrastructure for

179 the Olympic games of 1968 (Fig. 2C), followed by extensive residential areas and

180 commercial centers in the early 1970s (Fig. 2D). By now, the city has incorporated almost

181 the entire lava field, except for a few patches, which are under high stress (Cano-Santana et

182 al. 2006). The largest and best conserved of these patches is the "Reserva Ecological de San 
183 Angel" or REPSA, an ecological reserve with a core zone of 171 ha and a buffer zone of 66

184 ha that was created in 1983 inside UNAM (http://www.repsa.unam.mx; Zambrano et al. 185 2016). About 660,000 people currently live on the lava field (Hernández-Robles 2019), most 186 of them without knowing that they sleep on a bed of lava.

3. Characterization of the Xitle volcano area: Geological, environmental and additional values

191

192

\subsection{Geological processes and volcanology}

Xitle volcano is located in an area of intense and highly active volcanic, tectonic and sedimentary processes (Fig. 1). It is part of the Quaternary Sierra Chichinautzin volcanic field, which consists of more than 200 small volcanic edifices, most of them scoria cones and lavas (e.g., Bloomfield 1975; Martín del Pozzo 1982; Márquez et al. 1999; Siebe 2000; Arce et al. 2013). This volcanic field forms the central part of the active Trans-Mexican volcanic belt, a wide band that crosses Mexico east-west and includes stratovolcanoes, vast fields of small, monogenetic volcanoes, and some calderas (Fig. 1). The axial part of the belt is

200 affected by extensional forces that created a series of high-altitude ( $>2000 \mathrm{~m}$ asl) tectonic

201 basins, including the Mexico basin where the city is located (Fig. 1). The basins are filled by

202 lacustrine and volcaniclastic sediments and were occupied by shallow endorheic lakes that

203 have largely disappeared due to anthropogenic activity. The Xitle volcano is a strong marker

204 of this highly dynamic setting, as its cone was built on the border of the graben and its lava 205 interacted with one of the pre-existing lakes in the basin. 
In terms of volcanology, Xitle is a fine example of a basaltic scoria cone and

207 associated lavas, which are the most common volcanic structures on Earth (Fig. 3C; Wood

208 1980). This type of volcano is commonly called monogenetic, as they are formed by single

209 (mono) eruptions with one cause (genetic). While scoria cones are abundant along the Trans-

210 Mexican volcanic belt, basalts are atypical in subduction settings, and especially so the

211 alkaline, Ocean Island Basalt-type erupted at Xitle. This drives strong interest on this

212 particular volcano for geochemical studies on the source of magmatism in this region (e.g.

213 Straub et al. 2008).

214 Both the surface and the interior of Xitle lavas are exceptionally well exposed,

215 because soils are barely formed, due to the young age of the basaltic lava that is hard to erode

216 in the arid climate, and because of abundant quarrying due to the expansion of Mexico City.

217 Excavations have taken different forms with time. Large quarries made to extract building

218 stones were most prominent prior to the urbanization of the area. Important road cuts were

219 made when large avenues (Insurgentes sur, Periferico sur) were constructed, and now

220 excavation is restricted to small private areas, with the aim to construct underground parking

221 areas and to anchor structures against earthquakes. Most of these excavations and any

222 resulting exposures of the internal structure of the lava are however covered up when the

223 work ends, which reduces the number of long-lasting exposures that can be of use for

224 research or education. Early-on, the outcrops resulting from the active quarrying have

225 motivated the pioneering works of Waitz and Wittich (1910), Wittich (1919), Schmitter

226 (1953), and Badilla-Cruz (1977), and the more recent works of George Walker, the father of

227 modern volcanology, who revisited the early interpretations (Walker 1993, 2009). The many

228 sections cut though the lavas have also permitted numerous studies on the internal magnetic 
229 properties of basaltic lava flows (e.g., Cañon-Tapia et al. 1995, 1996). The quarrying is an

230 example how geoheritage can be promoted by extraction, if the exposures are accessible and 231 preserved.

$233 \quad 3.2$ Volcanic and seismic hazards

234 Due to its tectonic setting, Mexico City is surrounded by many young, active volcanoes and 235 hence exposed to significant volcanic hazards (Fig. 1, Siebe and Macías 2006). The most obvious source of hazards is the Popocatepetl stratovolcano, which has been in eruption since

2371994 and the ash of which occasionally reaches the city. However, the dormant Nevado de

238 Toluca volcano located $50 \mathrm{~km}$ west of the city and not visible from it (Fig. 1) has deposited

239 thick pumice layers in the Mexico basin, and is hence also a potential hazard that is unknown

240 to city dwellers. Another potential, yet unknown hazard is that of the formation of a new

241 monogenetic volcano within the Sierra Chichinautzin volcanic field. This is also a probable

242 impact even on Mexico City, as 14 such volcanoes (including Xitle) have erupted during the

243 last 15,000 yrs (Fig. 1, Siebe et al. 2004; 2005; Arce et al. 2015; Guilbaud et al. 2015). These

244 volcanoes are poorly known by the public, despite the famous eruption of the Paricutin

245 volcano in Michoacán in 1943-1952 (Luhr and Simkin 1993), being a classic Mexican

246 example. Xitle volcano is the most recent example of such type of volcano near the city, its

247 products are well-exposed, and there is clear evidence for its direct impact on human

248 settlement (see below). Hence, it is key to study and educate about hazards linked to

249 monogenetic eruptions in this area.

250 About seismic hazards, during the past centuries, Mexico City has been affected by large 251 magnitude earthquakes that have caused serious material damage and loss of life (e.g. 
252 Campillo et al. 1989; Singh et al. 2018). During those, the uneven distribution of the damage

253 revealed the crucial role of the ground firmness, the so-called site effect, on the intensity and

254 magnitude of the ground shaking. This then resulted in the zoning of the Mexico basin in

255 terms of seismic hazards and associated construction rules (e.g., Campillo et al. 1989; Flores-

256 Estrella et al. 2007). By being firm and located on the edge of the basin, Xitle lavas are a safe

257 area to live and work, and thus a testimony of the natural factors affecting seismic hazards.

258 It is noteworthy that the UNAM campus in the city hosts the Servicio Sismológico Nacional

259 (SSN) that is in charge of surveying the seismic activity in the whole country and informing

260 authorities and population (www.ssn.unam.mx). It is hence a key actor for the mitigation of

261 seismic risks.

\section{3.3 Hydrogeology, water resources, and flood hazards}

264 Typical for young basaltic lavas, the Xitle lavas have high hydraulic connectivity, which 265 means that water infiltrates quickly and percolates in the porous rock, forming aquifers

266 (Peterson 1972). For their specific topographic setting, the Xitle lavas act as a natural 267 conductor of rainwater from more humid, higher parts of the Sierra Chichinautzin, to the 268 drier, lower-elevation basin where springs occur (e.g. the Pumas quarry site, see pictures and 269 descriptions below). They also serve as a buffer to floods that occur every summer rainy 270 season in the basin, because the lavas soak up water. Despite the shortage of water resources 271 in the basin and common interference of construction works in them, the aquifer in the Xitle 272 lava is poorly studied and strongly impacted by anthropic pollution (Canteiro et al. 2019). Its

273 existence should be valued, and recognized as a means to increase the city's sustainability. 


\subsection{Biodiversity, ecology and environment}

276 Young basaltic lavas are a very peculiar substrate on which plant colonization is slow and

277 selective, hence fostering the formation of a specific ecosystem (e.g., Del Moral and Grishin

278 1999). The vegetation of the Xitle lava field has been mapped by Carrillo-Trueba (1995),

279 revealing a diverse plant pattern that varies mostly with altitude. While high-standing areas

280 (>2,500 $\mathrm{m}$ asl) are dominated by forests of pine tree, oak and fir (e.g., the vent area, Fig. 3C),

281 low-altitude areas $(<2500 \mathrm{~m}$ asl $)$ are mainly covered by a xeric scrub dominated by

282 Pitocaulum praecox that is native to Central Mexico (Rzedowski 1954) (e.g., the distal lavas,

283 Fig. 3D). The Pitocaulum praecox is a peculiar bush locally named "palo loco" or 'mad

284 branch', in Spanish, because it flowers in the dry season when the rest of the vegetation is

285 almost completely dry. This vegetation type is associated with a high biodiversity, having

286 almost 1,820 species of all taxonomic groups recognized, 32 of which are under protection

287 by Mexican laws and 54 of which are endemic to Mexico (e.g., Lot and Cano-Santana 2009;

288 Zambrano et al. 2016). The specifics of this ecosystem strongly rely on the peculiar

289 microtopography of the lava, which yields variable conditions of temperature, humidity,

290 light, and organic soil depth, promoting many biological adaptations in a climate alternating

291 between clear dry and rainy seasons (e.g., Castellanos-Vargas et al. 2017).

292

$293 \quad 3.5$ Archaeology and radiometric dating

294 Xitle has a profound significance for archaeology, as its eruption destroyed the first large

295 urban center of the Mexico basin (Cuicuilco). The abandonment of this site as a possible

296 consequence of the eruption coincides with the expansion of the city of Teotihuacan, located

297 further north, that became one of the largest urban areas in the world in the Classic period, 
AD 350-650 (e.g. Cummings 1926; González et al. 2000; Siebe 2000). Although it is yet to

299 be validated, as there are no historical accounts and radiometric dates for the eruption are

300 variable (see discussion in Siebe 2000), the eruption is pictured as responsible for a major

301 human disaster, as portrayed in paintings located in a small museum in the Cuicuilco

302 archaeological site and on the town hall of Tlalpan, a district of Mexico City that was

303 originally a village at the edge of the city (Fig. 3A).

304 Due to its archaeological significance and excellent exposure, the Xitle lava is the

305 most dated in Mexico, both by radiocarbon and paleomagnetic methods (e.g., Siebe 2000;

306 Urrutia-Fucugauchi et al. 2016). The first radiocarbon age that was acquired for this eruption

$307(2,422 \pm 250 \mathrm{yrs} \mathrm{BP})$ was one of the first ages obtained by the radiocarbon method worldwide

308 (Arnold and Libby 1951), which shows its importance for the development of a key dating

309 method for the Holocene and Late Pleistocene. Series of holes drilled in nearly every major

310 vertical section in the lavas reflect also its extensive use for the paleomagnetism calibration

311 that has a wide range of applications worldwide (Fig. 3B).

\section{$313 \quad 3.6$ Arts and aesthetics, architecture and cultural heritage}

314 The Xitle lava has been the source of abundant creative work, which expresses its

315 significance for the cultural identity of this area and makes it part of the intangible heritage.

316 The peculiar landscape formed by the lavas (locally called "Pedregal de San Angel") has

317 inspired many artists in the past, including painters like Diego Rivera, David Alfaro

318 Siqueiros, Gerardo Murillo ("Dr Atl") and Joaquin Clausell, photographers (Hugo Brehme

319 and Armando Salas Portugal), sculptors (Federico Silva, Helena Escobedo, Mathias Goeritz,

320 Francisco Soto), poets (e.g. Carlos Pellicer) and architects (Luis Baragan, Max Cetto house 
321 studio). It remains an inspiration for artists today such as Abraham Cruzvillegas, with his

322 provocative wall of trash named "Reconstrucción" (2016), illustrators like Aslam Narvaez

323 and Elvia Esparza, and many photographers who recognize the unique beauty of both the

324 lava forms and biodiversity. Several monuments of the "Ruta de la amistad" (route of

325 friendship), a series of 20 sculptures made by renowned artists in the southern part of Mexico

326 City for the 1968 Olympic games, were strongly inspired by the lava outcrops on which they

327 were built, and some of the artistic works remain placed where the lavas are nicely exposed

328 (Camarena-Berruecos 2010). The natural ecosystem formed over the lava and preserved in

329 the ecological reserve makes UNAM's main campus to be mentioned as the most beautiful

330 university in Latin America, and has been described as "a green oasis in the middle of a 331 megalopolis" (Krieger 2008).

332 As for architecture and cultural heritage, the Xitle lava has been used abundantly as building

333 stone for its aesthetic value, resistance to erosion and direct availability at construction sites.

334 The rocks hence form part of the architectural heritage of the area and contribute to its identity

335 inside the immense, multi-cultural megalopolis. In planning the exclusive "Jardines del

336 Pedregal" residential area that was constructed over the Xitle lava, Diego Rivera, probably

337 Mexico's best known and most emblematic artist along with his wife Frida Kahlo,

338 highlighted the benefits of the use of locally derived lava blocks that are valuable for their

339 homogeneity, solidity, low cost, and beauty (Rivera 1945). The Anahuacalli museum that he

340 built still hosts his collection of prehispanic objects and is a clear demonstration of these

341 precepts (Fig. 3E). These same ideas directed the planning of the central part of the UNAM

342 campus, which is considered as one of the most important architectural works of the last

343 century, and which was declared World Heritage site in 2006 (Technical report for UNESCO 
344 by the Coordinación de Proyectos Especiales, UNAM 2005). Another example is the house

345 called "casa del Indio" in the Coyoacán district that was built mostly by lava, by a famous

346 architect, Manuel Parra, for an emblematic Mexican actor (Emilio Fernandez) and that can

347 be visited. Besides these sites, the distinct light to dark grey microvesiculated Xitle stone is

348 part of many buildings, walls, stairs, and platforms in the SW corner of Mexico City, which

349 highly contributes to the aesthetics and sense of identity of this area of the city. Nevertheless,

350 its use is declining, and efforts should be made to promote it in the construction of new

351 buildings, in order to conserve the area's identity.

352

353

\section{Description of the geosites}

Palacio and Guilbaud (2015) identify and describe nine geosites in products from the Xitle volcano, six of them located within UNAM's ecological reserve. We revised this work, redefined the areas of interest, and describe below four sites that present the highest scientific, touristic and educational values, and hence highest significance for valorization and conservation, and are here considered as primary geosites or geosites sensus stricto according

361 to Brilha (2016). We also briefly refer to other sites with similar scientific values that

362 generally have more limited size and poorer state of preservation but can have local cultural,

363 educational or ecological significance. These could be considered as geodiversity sites

364 following Vereb et al. (2020). While Palacio and Guilbaud (2015) focused on volcanological

365 aspects, here we adopt a more holistic assessment and incorporate archaeological, historical, 366 educational and biological, ecological, and pedological considerations to highlight the 
multiple and diverse sources of interest of the sites and underline their importance for

368 geoconservation and geoeducation. Descriptions are rather long and complete at the sites

369 where these features had not been described before, to make a sound record and encourage

370 further investigation. The sites are located on Fig. 4 for further reference. We present a

371 quantitative assessment of the values of these geosites in the following section.

\section{$373 \quad 4.1$ Xitle vent geosite}

374 This site is located at high altitude, on the northern flank of the Sierra Chichinautzin range 375 (Figs. 1, 4). We first provide a short summary, and then describe the area in details, presenting maps of the volcanological elements (Fig. 5A, B) and the related vegetation pattern (Fig. 5C), and showing photographs of the main elements (Fig. 6). As developed below, this site has high geodiversity which is strongly and clearly linked with elements of pedodiversity and biodiversity, of significant scientific and educational interest.

381 Summary: This site contains typical, proximal products of Strombolian-style basaltic

382 activity (the weakest form of explosive volcanic activity) that are particularly well preserved and exposed. The area also features a range in vegetation cover and dominant tree species that are correlated with variations in the parental material (lava, scoria or tephra) and the overlying developed soil, the orientation of the cones' slopes (slope aspect) that controls the amount of solar insulation and humidity, and with the variation in altitude that allows different rainfall and humidity regimes. The dominant tree species are either endemic to Mexico or to Central Mexico, which is of biological relevance because of their associations and also have importance for their educational value. The position of the main cone on an

390 elevated plateau directly south of the city provides panoramic views of the Mexico basin and 
391 surrounding volcanoes that are both aesthetic and instructive. As for touristic values, this site

392 is a pleasant, green area with low atmospheric contamination that is easily accessible by city

393 dwellers. Numerous people go to this area in the weekends to enjoy small restaurants and

394 outdoor activities such as horse riding, hiking, and mountain biking. The walking paths are

395 easy and do not require specific equipment. For the cultural aspect, we have witnessed locals

396 engaged in religious ceremonies that take place near the main crater, but this aspect needs to

397 be investigated further in the future. Scientific values are described in more detail below,

398 distinguishing between volcanological, biological and pedological aspects.

399

400 Scientific interests. Volcanology: The vent area consists of a scoria cone (Xitle proper) and

401 a spatter and lava cone (Xicontle) that are aligned in a broad east-west direction, suggesting

402 a fissure (Fig. 5A, B). This type of 'monogenetic' volcano is the most abundant on the planet,

403 and its components are particularly well-preserved and well-exposed here. The alignment of

404 the Xitle and Xicontle vents highlights the ascent of the magma driving the eruption along

405 tectonic planes in the crust (faults), forming dikes that create a line of eruptive vents when

406 intersecting the surface. The scoria cone has a deep internal crater (50 m) and relatively steep

407 (ca. 30) smooth outer slopes (Fig. 5B), which probably explain the name of Xitle that means

408 belly button in the indigenous Nahuatl language. This morphology reflects the young age of

409 the cone whose original aspects have not been significantly affected by weathering. Small

410 paths allow the ascent of Xicontle and Xitle and follow their crater rim (Fig. 6A) and at Xitle,

411 descend to the bottom of the crater (Fig. 6B). The slopes of the scoria cone's crater have

412 gullies and small-scale landslides made of loose, bomb-size scoria, indicative of erosion by

413 colluvial transport that controls the morphological evolution of the crater (Fig. 6B).

414 Viewpoints offer clear views of the crater interiors, the southern part of the Mexico Basin 
415 (commonly covered by smog), and Ajusco's northern slopes, that are important components

416 of the general geological and geographical setting (Fig. 6C). On clear days, the Popocatepetl

417 and Iztaccihuatl stratovolcanoes that border the Mexico Basin to the east can be seen. Cuts

418 along the paths and gullies on the slopes expose the scoria cone interior that consists of an

419 alternation of scoria and ash layers (Fig. 6D), as well as lava bombs and short flows. Such

420 deposits are typical products of mildly-explosive activity that occurs at basaltic cones. In

421 contrast, Xicontle is made of a superposition of spatter layers and thin $(<1 \mathrm{~m})$ lavas exposed

422 in the crater, which are the products of lava fountaining that typically occur during weak

423 explosive activity along fissures. The good exposure of these products of weak to mildly-

424 explosive basaltic volcanism represents an educational asset. Of additional interest in this

425 area, is a lava flow unit to the east of the main cone that has no tephra cover, indicating that

426 it formed late, after the cone-forming explosions (Fig. 5A). These lavas host a system of

427 caves (lava tubes) linked to collapse structures (skylights), and some channels. The lava tubes

428 are important elements of basaltic lavas that strongly contribute to the large areas covered by

429 these flows, due to being very well insulated (Keszthelyi 1995). They are exposed as empty,

430 elongated cavities when their interior is drained, which probably occurred here at the end of

431 the eruption. These interesting aspects of the volcano are worth further investigation given

432 their relevance for understanding the recent, impactful volcanic activity close to Mexico City.

434 Pedology: There are interesting links between the elements of geodiversity of the vent area, 435 and other factors controlling the soil formation (relief, microclimate and organisms). 436 Variations in the topography in the vent area create some diversity in the soils. On the cone, 437 soils are formed from recently deposited unconsolidated volcanic ash and are hence shallow, 438 very stony, with incipient accumulation of organic matter and very weak structure, 
439 classifying as haplic Regosol, tephric, skeletic (humic) (Fig. 6H, Table 2, WRB IUSS

440 Working Group 2015). They are also highly porous and allow root growth to depths of up to

$44170 \mathrm{~cm}$. Soil depth and color vary with altitude, slope angle, and slope orientation. Soils are

442 deeper at higher altitude because of an increase in the amount and size of the deposited 443 unconsolidated tephra material. Steeper slopes have lower material stability, lower

444 accumulation and hence less soil depth. Slope orientated to the north causes shady, less 445 exposed areas to be more humid and have more trees and hence be more organic (darker 446 colored soils). In contrast, slopes with southern, sun exposure are drier and have light-colored 447 soils (Porta et al. 2019). Hence, the south-facing hillside inside the crater with a $35^{\circ}$ slope, 448 has low material accumulation, greater sun exposure, less humidity and a vegetation of grass 449 and few trees. The result is a shallow, light-colored soil, because of low organic matter 450 accumulation.

452 Biology: The vegetation in the vent area follows a pattern that matches the distribution of the 453 volcanological elements (cone, crater, lava), each of them presenting distinct soil types and 454 microenvironments due to variations in altitude and sun exposure (Fig. 5C). Our field 455 observations in February 2020 are generally consistent with the map of Carrillo-Trueba 456 (1995) although we noted some differences. The outer-slopes of the main cone that were 457 mapped as an alder forest by Carrillo-Trueba (1995), present a wide diversity of trees that 458 includes, in addition to alder (Alnus firmifolia, Fig. 6E), birch (Betula pubescens, Fig. 6E), 459 pine trees (Pinus teocote), widespread strawberry trees or madroño (Arbutus xalapensis, Fig. 460 6B, C, F), oaks (Quercus spp.) and yuccas (Yucca filifera, Fig. 6B). Vegetation inside the 461 crater is distinct from that on the outer-slopes and varies with the slope orientation. The north462 facing, slopes are covered by a fir forest (Abies religiosa, locally named abeto or oyamel, 
463 Fig. 6B) whereas the south-facing slopes are dominated by grass and small shrubs

464 (Muhlembergia macroura, Arctostaphylos pungens and Festuca tolucensis). Vegetation on

465 the lavas depends mostly on the tephra cover (Fig. 6C). Tephra-free lavas (late lavas) are not

466 cultivated and have just a few pine trees (Pinus hartwegii). In contrast, lavas that are covered

467 by tephra (early lavas) have a mature forest of Pinus teocote regenerated with Pinus

468 leiophylla (Fig. 6G), in addition to strawberry trees (Arbutus xalapensis), succulents (Sedum

469 oxypetalum) and grass. An area south of the cone that was not covered by Xitle lavas features

470 cultivated fields (Fig. 6C). Associated and conspicuous native vegetation in the area include

471 thistle (Cirsium ehrenbergii), tepozán (Buddleja cordata), boneset (Ageratina glabrata) and

472 maguey (Agave salmiana, Fig. 6A). All these plants are important hosts for pollinators such

473 as bats, nocturnal butterflies, hummingbirds, bees, wasps and beetles. Furthermore, the

474 different plant species live in symbiosis with different types of mycorrhizal fungi that are

475 extremely important for biogeochemical cycles and to maintain healthy soils, fulfilling many

476 ecological functions such as carbon sequestration, nutrient translocation, soil stabilization

477 and infiltration facilitator (Table 1).

478

479 Other sites with similar scientific value

480 Other cones of the Sierra Chichinautzin present similar characteristics, although the cone and

481 lava morphology, vegetation pattern, and soil cover vary widely with the volcano's age and

482 location (altitude, precipitation) giving a chronosequence of volcanic deposits and soils

483 (Peña-Ramírez et al. 2009). Cones that present particular interest for geosite development

484 due to their easy access and good level of knowledge are Teuhtli (Siebe et al. 2005; Guilbaud 
et al. 2015), Pelado (Lorenzo-Merino et al. 2018), Dos Cerros (Agustín-Flores et al. 2011;

López-Valdés 2019) and Chichinautzin (Peña-Ramírez et al. 2009; Reverchon et al. 2010).

\subsection{Cuicuilco geosite}

Summary: This site encloses an archeological and ecological park that is located at the

491 crossing of two main avenues in southwest Mexico City and several large shopping centers

492 (Loreto-Pena Pobre or Cuicuilco, Periferico Sur), and hence represents a natural green island

493 in a dense urban area with heavy traffic and a constant flow of people (Figs. 3D, 7A). The

494 park has a round pyramid that was surrounded and partly covered by Xitle lavas (Fig. 7A),

495 which superbly and very clearly illustrates the great impact of a relative minor eruption on a

496 major urban area at the beginning of our era (Gónzalez et al. 2000; Hubp et al. 2001). This

497 place is also strategic for inferring the pre-existing topography, climate and human

498 occupation, as well as the eruption chronology, through the study of the lava forms and the

499 deposits preserved below (paleosols, embedded artefacts, ash) (Figs. 7B-D; Solleiro-

500 Rebolledo et al.2016). In addition, it includes a patch of the lava field with typical landforms

501 and associated flora and fauna, that can be observed along pleasant walking paths (Fig. 7E).

502 The top platform of the pyramid provides clear views over the southwest corner of the

503 Mexico basin and the northern slopes of the Sierra Chichinautzin, featuring specifically the

504 Xitle cone and Ajusco stratovolcano. On clear days (a rare occurrence), the Teuthli cone and

505 the Popocatepetl stratovolcano can be seen to the southeast. Of cultural and artistic

506 significance, the recently-restored sculptures and monuments of the "Ruta de la Amistad"

507 (friendship route) built directly on the lava can be observed on a nearby roundabout 
508 (Camarena-Berruecos 2010). Onsite, there is a small museum that presents basic information

509 about the setting and archaeological findings. There is also a painting representing the

510 destruction of the pyramid by the Xitle eruption.

511

512 Archaeological interest: The rounded pyramid is one of the few existing in Mexico and is,

513 with the exception of small mounds nearby, the only remaining building of Cuicuilco City

514 (Cummings 1926). Cuicuilco (700 BP-150 AD) is considered the first major urban center in

515 the Mexico Basin (Heizer and Bennyhoff 1958), with a peak occupation of $>20,000$

516 inhabitants (Sanders et al. 1979; Parsons 1989). Its great economic and political power is

517 reflected by a majestic complex of buildings surrounding a temple with a conical truncated

518 base, about $110 \mathrm{~m}$ in diameter and $20 \mathrm{~m}$ in height (Kelly 1982). There is still considerable

519 debate over whether the eruption directly caused the abandonment of Cuicuilco and the

520 migration of its population to Teotihuacan or if both events are not connected. If it did, then

521 the eruption caused a major natural disaster (e.g, Heizer and Bennyhoff 1958, 1972; Córdova

522 et al. 1994; Siebe 2000; Urrutia-Fucugauchi et al. 2016).

524 Scientific interests. Stratigraphy and paleoenvironment: The archaeological excavations

525 created numerous cuts through the lava that reveal the vesicular interior of the flows and,

526 more peculiarly, the surface below. A tunnel excavated below the lava exposes from top to

527 bottom: the billowy base of the lava that is proof of its emplacement as inflating pahoehoe

528 lobes, a thin reworked dark ash layer produced by early explosive activity at the cone, and a

529 buried soil (paleosol) that is locally indurated and transformed into red brick due to the lava

530 heat (Fig. 7B, Solleiro-Rebolledo et al. 2016). Such a succession very clearly shows the 
531 chronology of events that occurred at this important site, being hence of scientific and

532 educational value. This paleosol preserves important information on the paleoclimate and

533 human occupation at the time of the eruption (Solleiro-Rebolledo et al. 2016). The ash below

534 the lava is locally finely stratified, indicative of an intense activity with rapidly-succeeding

535 strong explosions, and the basal layer contains bits of charcoal which were likely produced

536 by the burning of vegetation along the advancing lava flow front (Fig. 7C, Siebe 2000). South

537 of the archaeological park, a cut along a carpark in a commercial center exposes rounded,

538 pillow-like lava forms that suggest the existence of shallow water in that area at the time of

539 the eruption (Fig. 7D; Plaza Cuicuilco in Palacio and Guilbaud 2015). This confirms other

540 inferences that the pre-Hispanic city was located in a deltaic plain, at the convergence of river

541 streams that flowed down the slopes of Ajusco (e.g., Córdova et al. 1994). Exposed recent

542 pillow lavas are a rare feature, giving particularly high importance to this site.

543

544 Other sites with similar scientific value

545 The contact of the lava with the underlying ground, with a thin ash layer and locally-burnt

546 paleosol with archeological artifacts, can also be seen in several sites in UNAM, indicative

547 of the large area occupied by settlements that were affected by early ash from Xitle (Entrada

548 Principal and Campo de Beisbol in Palacio and Guilbaud 2015). Graves and diverse types of

549 objects were found in the paleosol in the Copilco quarry located north of UNAM (Gamio

550 1920). However, this important site that was public from the 1920 s to the early 1980 s

551 (Solleiro-Rebolledo et al. 2016), is now only accessible after specific request, from the

552 offices of the National Institute of Anthropology of Mexico.

553 


\subsection{The Geopedregal geosite}

\section{5}

556 Summary: The ecological reserve of UNAM is the largest remaining area where the distal

557 part of the Xitle lava flow field and its related ecosystem can be observed. Because of the

558 need for conservation and the high potential threats, the core part of the reserve is closed to

559 visits, but the campus encloses a total of 48 ha of "pedregales remanentes" that are remaining

560 patches of the lava field not destroyed by infrastructure and not covered by a thick layer of

561 construction material waste forming anthropogenic Technosols (SEREPSA, 2008). The

562 Geopedregal site was created in 2012 on a ca. $3000 \mathrm{~m}^{2}$ lava outcrop located on land shared

563 by the institutes of Geology and Geography. The site, originally used as dump, was cleaned,

564 restored and converted into a small park. This exposes in a preserved environment the main

565 aspects of the lava morphology and related biological adaptations, ecosystem services such

566 as thermal regulator, pollution buffering and pollinator corridor of bats, bumble bees and

567 butterflies, as well as water capture by infiltration. It is also an aesthetically pleasing area

568 (González et al.2016). The site is used to conduct several research programs, field work, and

569 science education for school and university students of different levels. It is also used for

570 photographic expositions and guided visits, as well as local festivities that draw people from

571 the nearby research centers to the site and help to secure its existence (see Electronic

572 Supplementary Material and http://www.geologia.unam.mx/contenido/geopedregal). It is the

573 first "pedregal remanente" of the University campus with a whole program of restoration,

574 which is protected by the University laws (Zambrano et al. 2019). 
576 Scientific interests. Volcanology: Lava structures in the Geopedregal site are varied and

577 characteristics of a hummocky pahoehoe lava field like that observed in Kilauea volcano,

578 Hawaii (Hon et al. 1994). This type of lava surface morphology has not been described

579 elsewhere in Mexico, because of the rareness of basaltic magmas along the volcanic belt,

580 hence being relevant for investigation and education. The main lava structures consist on an

581 elongated, planar sheet lobe with steep lateral margins and an oval dome-shape tumulus with

582 axial and lateral clefts, that are separated by a depression (lava rise pit) (Fig. 8A). There are

583 also: an area with complex ropey features caused by folding of the thin and still-plastic, hot

584 lava crust during emplacement (Fig. 8B), an artificial cut that exposes the vesicular upper

585 crust of the sheet lobe (Fig. 8C), an elongated cave that formed by partial lateral collapse of

586 a tumulus (Fig. 8D), and two connected semi-circular 1.5 m-deep cavities that probably

587 formed by roof collapse of a local tube (skylights, Fig. 8E). The lava's microtexture varies

588 from smooth and slightly spiny to folded and show toothpaste type texture in places. The

589 variety in lava morphologies in this small area makes it particularly geodiverse and gives it

590 high didactic value.

591

592 Pedology: The age of the emplaced lava is less than 1700 years and therefore soils are very

593 shallow $(<4 \mathrm{~cm})$ and located only in small morphological depressions, allowing almost a

594 continuous rock surface. They contain less than $20 \%$ of fine particles and low amounts of

595 nutrients as cations $(\mathrm{Ca}, \mathrm{Mg}, \mathrm{K}$ and $\mathrm{Na}$ ) but high organic matter, classifying as nudilithic

596 Leptosol hyperskeletic distric soils (Fig. 8F, Table 2, Siebe et al. 2016). From the point of

597 view of soil quality, one could say that site quality is poor: soil texture is coarse, causing

598 excessive drainage and low water holding capacity, nitrogen retention is limited because the 
599 organic horizon is thin, but the main function of these soils is infiltration and aquifer recharge.

600 The diversity in lava morphology in terms of slope, roughness, and fracture pattern, and

601 associated soil thickness, produces high biodiversity through the crucial role of microsites

602 (or microhabitats) (Cano-Santana et al. 2006; Castellanos-Vargas et al. 2017).

603 The lavas around the Geopedregal have been covered with anthropic materials introduced in

604 the early 1970's to build the green landscaped areas of the university covered with lawn,

605 where technosols are developed that are now at least $1.5 \mathrm{~m}$ thick (Fig. 8G). These two

606 contrasting types of soil (natural vs antropogenic) allow us to explain the ecosystem services

607 provided by the natural lava soils.

608 Biodiversity: Depending on the microhabitats with differential temperature, humidity and

609 light conditions diverse plant species and community consortia can develop. These range

610 from cryptobiotic saxicola crust (crust made by organism growing directly on the rock) made

611 by an association of cyanobacteria, lichens, and bryophytes, to scrub vegetation dominated

612 by the "palo loco", agaves and several terrestrial orchids. Some trees species ("Tepozán":

613 Buddleja cordata, Fig. 8E, "Encino": Quercus rugosa, "Copal": Bursera fagaroides and

614 Bursera cuneata) grow in skylights and deep inflation clefts. "Orejas de burro" (Crassulasean

615 Echeveria gibbiflora) typically grows in fractures and shallow inflation clefts as well as

616 cactus ("nopal": Opuntia tomentosa, Mammillaria magnimamma and the endemic

617 Mammillaria haageana san-angelensis), and the bat-pollinated agave Manfreda

618 brachystachya grows on flat surfaces exposed to abundant sunlight. The irregularity for the

619 surface and the presence of caves also promotes significant diversity in fauna, such as local

620 mammals and insects (marsupial "Tlacuache" Didelphis virginiana, ringtail "Cacomixtle" 
621 Bassariscus astutus, rodent "Ratón piñonero" Peromyscus gratus gratus, and the endangered

622 bat Leptonycteris curasoae).

\section{Other sites with similar scientific value}

624 Some sites in the reserve buffer zone also allow visitors to observe the peculiar lava 625 morphology and partly restored ecosystem (Jardín Botánico, Senda Ecológica and Espacio 626 Escultórico, in Palacio and Guilbaud 2015). In some places in the UNAM campus and 627 around, the lava surface is periodically cleared of invading grass (mostly for aesthetic 628 purposes), conveniently exposing the lava's microstructures and textures. Outside of UNAM, 629 the lava and vegetation are partly preserved in localized parches in the Cuicuilco site (Fig. 630 3D), the "Bosque de Tlalpan" (ID8 in Palacio and Guilbaud 2015), the Huayamilpas park in 631 Santo Domingo, "Los Encinos" area near the Colegio de Mexico, the main avenue of the 632 "Jardínes del Pedregal" residential area, and the Anahuacalli museum (location of sites on 633 Fig. 4; Cano-Santana et al. 2006; Camarena-Berruecos 2010).

\section{4.4 The Pumas Quarry geosite}

637 Summary: The "Cantera Oriente" (eastern quarry in Spanish) is located at the eastern border 638 of the UNAM campus (Fig. 9A). Despite its location near to one of the busiest metro stations 639 of the capital (Universidad station), this place is very quiet green area that was restored with 640 exotic plant species and contains a lake. This site is known informally as the "Cantera de los

641 Pumas" because it encloses the training grounds of the infamous "Pumas" UNAM football 642 team, and visits are allowed only by appointment. The 7.5 ha area belongs to UNAM but was 643 exploited by the city from 1970 to 1994 (Lot 2007). The remaining artificial cuts of the quarry 
644 walls display spectacular exposures across an up to $40 \mathrm{~m}$-thick pile of inflated pahoehoe

645 flows (sheet lobes and tumuli). These are continuous over a lateral distance of 900 meters 646 and consists of five main vertical units (Figs. 9B, C; ID2 in Palacio and Guilbaud 2015). The

647 high total thickness of the lava and its complex internal structure points to years of slowly 648 advancing lobes, progressively filling a large depression (Guilbaud and Siebe 2009). Water

649 springs emerge from fractured areas near the base of the lava pile (Fig. 9D) and feed a pond 650 or small lake that covers $12,000 \mathrm{~m}^{2}$ (Fig. 9E), demonstrating the role of the lava as an aquifer.

651 This small lake is surrounded by a green area managed by the reserve that has some interest 652 in biology and ecology (Lot 2007) as for example the conservation of the endemic Mexican 653 salamander Ambistoma mexicanum.

654 Scientific interests. Volcanology and paleomagnetism: The "Cantera Oriente" is the 655 largest remaining quarry in the Xitle lava which has not been urbanized and where the lava 656 can still be easily seen and accessed for sampling, which is of considerable interest for 657 scientific studies. As introduced in section 3, the Xitle lava is probably the most excavated 658 young basaltic lava in the world, due to the growth of one of the largest cities in the world, 659 first near its margins and then directly on it. Excavhat respect, the Pumas quarry is the locatin 660 where, to our knowledge, the thickest pile of young basaltic lava fed by a single eruption has 661 been found in Mexico. Such continuous vertical exposure provides an excellent opportunity 662 to study changes in the properties of basaltic lava at both small spatial and short temporal 663 scales. Samples from this site have thus been used to assess the consistency of paleomagnetic 664 measurements (Alva-Valdivia et al. 2005) and a study of lava's chemical variations at that 665 location is ongoing, with the aim to shed light on processes taking place during such 666 monogenetic eruptions. This site is also important for interpreting the mode of growth of the 
667 lavas by the inflation process (or swelling) that creates the specific internal structure of the 668 lava (vesiculated crust at the base and top, dense core) and the formation of the sheet lobes 669 and tumuli that have planar and uplifted geometries, respectively. These features that are

670 exceptionally well displayed by the quarry walls, are typical of pahoehoe lavas observed in 671 a wide range of settings and diagnostic of long-lived, far-reaching lava flows (Self et al. 672 1998). They are hence significant for the study and understanding of effusive basaltic 673 eruptions worldwide.

674 Biology and ecology: Environmental and ecological aspects of the Pumas quarry are 675 significantly distinct to other parts of the ecological reserve, motivating their management as 676 a separate entity, and the publication of a dedicated field guide by Lot (2007). The specificity 677 of the area and its main interest is the lacustrine environment that is now rare in the Mexico 678 Basin but was common in the past, prior to drainage of the paleolakes. In that respect, this 679 area may be considered as a snapshot of the pre-urban environment in the Mexico Basin. 680 Rather unexpectedly given the high degree of transformation of the area and introduction of 681 exotic species, the small lakes contain a rich aquatic fauna and flora, many of these native, 682 endemic, of restricted distribution, and some even relict or rare elements with respect to their 683 presence in the Mexico Basin (Lot 2007). The isolation of this area that is surrounded by an 684 up to $40 \mathrm{~m}$ wall of lava and which access is restricted, makes it an ideal laboratory for 685 research investigations, and gives it high landscape and aesthetic values.

\section{Other sites with similar scientific value}

688 There are many other places in UNAM where the typical internal structure of inflated 689 pahoehoe is displayed, although at smaller scale than at the Pumas quarry. A site at the main 
entrance of the campus displays a long and continuous vertical cut in a sheet lobe (ID5 in

691 Palacio and Guilbaud 2015). There are also deep cuts along the northwestern side of the

692 Olympic Stadium, in the "Casa Club del Académico", and along Insurgentes, the main

693 avenue that crosses the University. These sites are extensively used for rock climbing,

694 including by professionals for training, another interesting use of vertical lava outcrops.

695 Many other ancient quarries in the Xitle distal lavas were converted into housing 696 complexes or commercial centers, where the internal structure of the lava is still exposed in 697 places (for example: Copilco, La Cantera, Oasis). It is fairly common to find large outcrops 698 inside schools, gardens, house basements etc., across the entire flow-field, and several located 699 along the most distal limit of the flows in the Coyoacán District include water springs from 700 the lava base.

\section{State of conservation and risk of degradation of the proposed geosites}

Exposures of the Xitle volcano and its lavas are threatened with serious damage to complete disappearance, due to the uncontrolled expansion and densification of Mexico City in the southwestern part of the Mexico basin (Cano-Santana et al. 2006; Hernández-Robles 2019). In most urbanized parts of the lava field, the original landform is hardly recognizable, and rock outcrops are scarcely found, being completely covered by concrete. Despite their

710 significance, all the geosites described in this paper show signs of degradation and constant

711 threats from building over. Despite being part of conservation land ("suelo de conservación",

712 GDF 2012), the vent area is invaded by illegal settlements that cover an increasing part of 
713 the area and damage irreversibly the volcanic products and associated biodiversity (Pezzoli

714 2000; Aguilar and Santos 2011). During the last decades, the Cuicuilco archeological site

715 was severely fragmented and partly destroyed in order to build a large commercial center, as

716 well as governmental and commercial offices. Only recently, a program was initiated to

717 restore part of it, but the destruction is irreversible (Pérez-Galicia and Pérez-Campuzano 718 2015).

719 The UNAM campus that was the first large area of the lava that was urbanized is now, 720 paradoxically, the largest preserved area. The ecological reserve that is the main actor in this

721 conservation has continuously expanded since its formation, but the ecosystem is severely

722 damaged, in a large part due to the introduction of exotic species, and it is subject to abundant

723 and highly diverse threats directly related to the high traffic of people and cars within the

724 university city (e.g. 70,000 cars per day, Zambrano et al. 2016). The annual budget and

725 human resources of the reserve are clearly insufficient to restore and protect this area, and its

726 very existence is not guaranteed as it relies on a decree that could easily be canceled by the

727 rector of the university. The UNESCO World Heritage nomination guarantees the

728 preservation of the architectonic heritage in the center of the campus, however the lavas are

729 not mentioned in the description of the property, and are hence of low relevance for UNESCO

730 at this moment.

731

732 6. Quantitative assessment

733

734 To evaluate quantitively the significance of the proposed geosites and compare their 735 scientific, educational and touristic values, we applied the assessment method of Brilha 
736 (2016), and show a summary of the results in Table 3. Specific methods have been developed

737 for assessing the touristic values of urban geomorphosites (Clivaz and Reynard 2018; Pica et

738 al. 2016, 2017), nevertheless, we argue that the more general method of Brilha (2016) allows

739 a useful comparison of the Xitle geosites and effectively highlights the elements that impact

740 negatively on their value and may be improved in the future. Besides, the Xitle geosites are

741 all visible landforms whose value assessment does not require considering abundant

742 archaeological and historical data, such as for deeply transformed, "invisible"

743 geomorphosites in European cities (Nistor et al. 2017; Pica et al. 2017; Ticar et al. 2017;

744 Clivaz and Reynard 2018).

745 Results show that in terms of scientific value, the vent area ranks first, closely

746 followed by the Cuicuilco site, then the Pumas quarry, and last, the Geopedregal site. Such

747 ranking mostly reflects the lack of international publications and lesser geodiversity for the

748 latter two, while the vent area is more geodiverse for the variety in geoforms and volcanic

749 products, and has less use limitation (i.e. for sampling) than Cuicuilco. However, in terms of

750 touristic and educational potential, the vent area ranks last for its higher vulnerability

751 (because of illegal settlements and no fencing) and lack of dedicated parking area and safety

752 facilities (stairs etc). Cuicuilco ranks first in these categories for its ease of access by groups

753 and its uniqueness.

754 For the vent area, restricted access could be balanced by viewpoints and the score

755 could be increased for facilities with a dedicated investment in infrastructure. The publication

756 of ongoing research at the Pumas Quarry and Geopedregal sites will soon increase their

757 scientific value. 

the highest grade for representativeness, integrity, association with other values, observation conditions, and didactic potential, which is consistent with our purpose (they were selected precisely for these criteria). However, they all have low scenery value, given that the criterion used by this method is the promotion of the sites by touristic campaigns that are non-existent

763 for natural sites in Mexico City. Nonetheless, the city setting promotes their proximity to 764 large accommodation facilities and recreational areas, a high population density, and high 765 economic level (compared to national average). The way the geoheritage value of the geosites could be enhanced is discussed in section 7.4 below.

\section{Benefits of the Xitle geoheritage to the city}

771 Based on our study of the Xitle geoheritage, we review more extensively its relevance for

772 wider issues such as nature preservation and sustainability (7.1), social equity (7.2), and 773 awareness on natural hazards (7.3). We finally expose an existing initiative led by academics 774 at UNAM to promote this geoheritage and point to avenues for an amplification of these, to 775 guarantee the preservation of the sites and foster their sustainable use by the city (7.4).

7.1 Relevance for nature preservation, ecosystem services and sustainability in the context of urban development

779 Geosites are celebrations of nature and its link with humanity. In cities, nature tends to 780 disappear under the pressure for construction and economic growth. Geosites are hence 
781 crucial for preserving remnants of natural elements in an otherwise sterile environment, and

782 should be considered as a key component for conservation (Gordon et al. 2018). Xitle

783 geosites are particularly important in that respect, for the close relationship that exists

784 between their geodiversity and the associated diversity in soils (pedodiversity) and flora and

785 fauna (biodiversity). The Mexico Basin has suffered extremely rapid and destructive urban

786 growth during the last 50 years, and the preservation of the last remains of fauna and flora

787 that is endemic of this region and unique in the world strongly relies on the conservation of

788 the Xitle lavas, whose elevated diversity in morphology and vesicularity creates a wide range

789 of microhabitats that host a considerable number of species (e.g., Estañol-Tecuatl and Cano-

790 Santana 2017).

791 Moreover, Reynard et al (2017) argues that, in addition to being sites of interest for society

792 that are located within the limits of the urban space (lato sensu definition), urban geosites

793 can be places that help understanding the interaction between geological forces and urban

794 development (stricto sensu definition). The Xitle geosites are a good example of urban

795 geosites stricto sensu, as they remarkably conserve the testimony of the long-lasting

796 interaction of volcanic activity with human development, during a ca. 2,000 years period

797 stretching from the eruption until today. Xitle lavas initially destroyed an early, large human

798 settlement in the basin, creating a strong link between the geoheritage and the archaeological

799 heritage of this region. Then, they slowed the expansion of the city because they were

800 difficult to build on, hence controlling the pattern of urban development in the southwestern

801 corner of the basin (note that main avenues surround the lava field's border, Fig. 4). Now

802 they host the last natural areas and the country's main university, providing multiple

803 ecosystem services to the city (habitat provision for endemic plants and animals, mitigation 
804 of flooding and damage by earthquakes, source of building and ornamental stones, water

805 filtration and storage, recreation, outdoor sport, culture, identity, science knowledge and

806 education). The conservation of the open lava surface is particularly important for

807 sustainability as its destruction through its coverage by cement, constructions or

808 impermeable, exotic soils reduces drastically its capacity of infiltration, and hence preserving

809 the original landforms is important for preserving water resources that may be fundamental

810 in the future (Canteiro et al. 2019; Zambrano et al. 2019). In the UNAM campus alone, the

811 cost of conserving open green areas with exotic tree species and lawn is very large in terms

812 of water for irrigation, whereas the natural ecosystem sustains itself through the natural

813 capacity of the lava to store water and the low requirements of water by endemic plants

814 (Camarena-Berruecos 2010). In conclusion, the Xitle geoheritage should be explicitly

815 included in natural conservation plans and urban planning strategies for the southwestern

816 corner of the Mexico Basin, because of the multiple benefits it provides for the area.

\section{$818 \quad 7.2$ Relevance for providing well-being and reducing social inequalities}

819 Nature preservation in cities strongly depends on urban planning and associated construction

820 rules. These can vary spatially within cities, especially in countries with high inequalities

821 such as Mexico. The preservation status of outcrops and associated biological elements in

822 the urbanized part of the Xitle lava field varies widely, reflecting the economic and social

823 segmentation of the city. Rich neighborhoods (e.g. Jardines del Pedregal) preserve outcrops

824 and associated vegetation in nice parks, gardens and, occasionally, caves in house basements,

825 while in poor neighborhoods (e.g. Santa Ursula, Santo Domingo), every bit of lava is covered

826 by concrete, vegetation is sparse and almost all non-native (Fig. 10), and the few remaining 
outcrops are used as dumps. The origin of such dichotomy is historical, as rich districts were

828 designed by architects and engineers, whereas poor neighborhoods grew chaotically, from

829 illegal settlements. These initial disparities were then amplified by the limited public funding

830 to restore and maintain green areas. Hence, the remaining state of the lava outcrops in the

831 city and quality of the environment (lamentably) reflects the distribution of economic wealth,

832 amplifying social inequalities.

833 An important and highly-valuable exception to this, is the UNAM campus that

834 preserves the largest ecological reserve of the area and numerous outcrops scattered across.

835 Such areas are well maintained and accessible to all. The recently-rehabilitated Huayamilpas

836 park that is located in a popular district nearby is another public area that conserves a patch

837 of the lava field. These natural green areas provide wellbeing for city dwellers, in particular

838 those that have precarious housing, low-value jobs, and complex socio-economic conditions

839 that do not allow them to travel to more natural, rural areas. Because they include walking

840 and cycling paths, as well as climbing walls, the parks promote physical activity, of particular

841 relevance in Mexico where child and adult obesity is among the highest worldwide. In

842 addition to such services, we argue below that lava patches within the city should be used to

843 disseminate information and raise awareness about natural hazards.

\section{$845 \quad 7.3$ Relevance for mitigation and education on natural hazards}

846 Nature under pressure increases dramatically the impact scale of natural hazards. At the time

847 of writing, the Covid-9 pandemic is putting under lockdown at hundreds of millions of people

848 worldwide, with tragic social, economic, and political impacts. Although this event has

849 complex, multi-factual sources that will require years of investigation to untangle, it may be 
considered as an example of a small natural hazard (a virus hosted in an animal) that turned

851 into a global disaster, partly due to the increasing interference of humans on wildlife and the

852 environment (e.g., Bonilla-Aldana et al. 2020). Geosites are ways we can, as a community,

853 restore links between society and nature, and acknowledge its relevance for our past, present

854 and future. It also allows to promote a better communication and thrust between the

855 population and the scientific community, which would allow, in the long term, to better 856 mitigate hazards.

857 Geological hazards are an important and increasing threat to society simply because

858 of population growth and the increasing densification of urban areas in hazardous locations.

859 Such risk needs to be better recognized, to avoid both large scale disasters in the future, and

860 mitigate smaller, chronic ones that have a high social cost. Mexico City is an area where

861 volcanic hazards are high, but most people lack formal education in geology and poorly

862 understand the processes involved, creating the need for geoeducation. The Xitle area is a

863 location where the impact of geological activity on society is well exposed, and can be hence

864 easily divulgated. The Xitle eruption was a minor volcanic event in terms of magnitude, yet

865 its impacts were great. The pyramid surrounded by lavas (Cuicuilco archeological site) is a

866 clear physical evidence for past effects. At present, the impact of the lavas is mostly positive

867 as they help mitigate chronic hazards such as inundations that occur every rainy season in

868 the basin, and earthquakes that occur on a monthly to yearly base. The Mexico basin is a very

869 dynamic system, both geologically and humanly, stressing the need for more holistic studies

870 on human and hazard interaction, to minimize the risks. We argue that the preservation and

871 investigation of the Xitle geoheritage is fundamental to better understand, mitigate and 872 inform on natural hazards in Mexico City. 
874 7.4 Local sustainable development and geoeducation through geoheritage: Ongoing 875 initiatives and future opportunities

877 Our study provides some insights about how the urban geoheritage could be promoted and

878 enhanced. The quantitative assessment of the geosites shed some light into how the value of 879 these and other sites could be improved, in order to envisage the creation of a geotouristic 880 attraction such as an urban geopark.

881 The low scenery value of the sites is a feature that is common to all urban geosites as 882 they are of small size and immersed into a dense urban framework with tall buildings (Pica 883 et al. 2017). Therefore, they are poorly known by locals and even less by city tourists, and 884 strategies are required to enhance their visibility. Their advantage however, in comparison to 885 most rural sites, is that they tend to be associated to significant additional cultural values, 886 such as archaeology and history for Rome (Pica et al. 2017). Geosites at Xitle have great 887 environmental (Xitle vent area), archaeological (Cuicuilco), ecological (Geopedregal) and 888 recreational (Pumas quarry) values that are better known by the general public than their 889 geological attributes. Such linkage should be used to draw people to the sites, to infuse them 890 with geological knowledge.

891 Another clue to promote urban heritage is to involve local university and educational

892 centers that are located near the geoheritage elements. As highlighted above, the UNAM 893 campus is a key area for the preservation of Xitle geoheritage. The university is also the main 894 research and education hub in the country. It should hence have a leading role in promoting 895 such heritage. The two UNESCO Geoparks in Mexico (Comarca Minera and Mixteca Alta) 
that were nominated in 2007, were initiated by UNAM-based research groups and arose from

897 the joint participation with municipal authorities, ejidatarios (managers of communal lands),

898 and the local population. The geoparks continue to receive UNAM support through research

899 projects, but they are managed by locals who are also the main beneficiaries.

900 The Geopedregal in the UNAM campus is the only geosite in the area with a planned

901 series of educational activities related to the natural features present there, hence being an

902 example to follow. Initially focused on the biological and ecological aspects, activities were

903 gradually expanded to include geological aspects, in the context of the UNESCO Geoheritage

904 for Geohazard Resilience project (ICGP 692). In 2019, the site obtained a certification to be

905 incorporated in a national-wide program of school visits, which strongly promotes its

906 educational use. The area itself is small, which limits the size of groups and number of

907 features to be observed, but ideas for future development involve using it as a starting point

908 for "geowalks" around the UNAM campus that would include other interesting sites. Cultural

909 activities at the Geopedregal involve organizing social events that are highly important in

910 Mexico, for example the "Dia de Muertos", the 1" of November, for which people make

911 highly elaborate and creative altars for the missing, or the posadas that occur 9 days before

912 Christmas and consist in gatherings during which a meal is shared and a "piñata" is destroyed

913 (Electronic Supplementary Material). Those initiatives allowed the site to be known by many,

914 increasing its visibility and promoting its conservation in the future. This is an example of

915 how the conduction of cultural activities can help raise awareness on local geology and

916 ecology. The preservation of this site in the long term would although require hiring

917 permanent, specifically-dedicated personnel as much of the needed maintenance work and 
918 teaching is currently done by students. Didactic material incorporating geological

919 information should also be developed and published formally.

920 The experience gained at the Geopedregal should be used to develop other sites in the

921 UNAM campus (for example a similar incipient project at the science faculty, or the Senda

922 Ecologica near to the science museum Universum). The methods developed at UNAM should

923 then be applied to the other geosites highlighted in this study, in close collaboration with the

924 community and local actors, such as archaeologists at the Cuicuilco site, local guides at the

925 "parque ejidal San Nicolas Totolapan" (a recreational park located near the vent area), and

926 coordinators of the UNAM reserve and soccer training grounds at the Pumas quarry. People

927 and organizations in charge of other interesting sites such as the Huayamilpas park, the

928 Anahuacalli museum and the "Jardines del Pedregal", could also be contacted, to promote

929 the realization of geo-related outreach activities, such as the installation of information panels

930 or the organization of activities and school visits. In the long-term, all these initiatives could

931 be merged to develop a geopark in the Xitle area.

932 With respect to international recognition and protection, the UNAM campus already

933 hosts a UNESCO Word Heritage site, but the nomination is purely cultural. Several aspects

934 of the property are however strongly tied to the geology, as the acclaimed architecture include

935 Xitle stone and was inspired by the original land aspect. The location of the UNAM campus

936 itself is closely related to the lavas as they were the last un-urbanized spot at relatively close

937 distance from the city center. There is hence potential to build a proposal to include the

938 geological aspect in the nomination and make it a mixed site (natural + cultural). This study

939 provides the foundation of such an initiative that should engage a wide range of academics

940 and students from different faculties and research institutes in the themes of science, 
941 architecture and arts, as well as UNAM authorities, the local government (Delegación de

942 Coyoacán) and the government of Mexico City.

943

\section{8. Conclusions}

945

946 Geoheritage in cities is commonly destroyed and undervalued, despite its significance for a

947 wide range of issues that include nature preservation, education on natural hazards, and

948 environmental sustainability.

949 Mexico City is a large, densely populated area with serious environmental and social

950 problems that is also exposed to a multitude of natural hazards. The Xitle volcano provide

951 one way, through Geoheritage, of dealing with some of the city's problems. The Xitle

952 eruption produced a small cone and an extensive lava field that have been incorporated into

953 the city during the last 50 yrs of uncontrolled development.

954 We have chosen four exceptional geosites that expose major elements of geodiversity,

955 biodiversity and pedodiversity, and which link with anthropic activity, and hence are key

956 locations for educating on sustainability and natural hazards. The geosites also provide ways

957 to preserve the remaining natural spots in the city. They can be used to bring people to

958 understand the relationship between volcanic and human activity, conserve and value key

959 elements of the city's identity, improve human wellbeing, help lower social inequalities, and

960 raise awareness on risks.

961 Urban geoheritage commonly lacks visibility, which could be improved by valuing

962 the cultural values associated to the sites, and engaging local actors such as educational

963 centers. Existing educational projects such as the Geopedregal at the national university 
964 should be consolidated and used as a basis to develop community-based projects at other 965 sites. Initiatives such as creating an urban geopark or converting the UNESCO Word

966 Heritage cultural site of the university campus to a mixed cultural-natural site, should be

967 considered as ways to ensure the conservation of the Geoheritage and its multiple benefits to 968 the city.

969 In general this work shows how geoheritage developed on important geosites can 970 incorporate all environmental, cultural and social aspects, and how they could be used to

971 maintain an awareness of the environment and natural hazards in an urban context.

972

973

974 Electronic Appendix

975

976 Slide with pictures of activities in the Geopedregal site.

977

978 Figures 

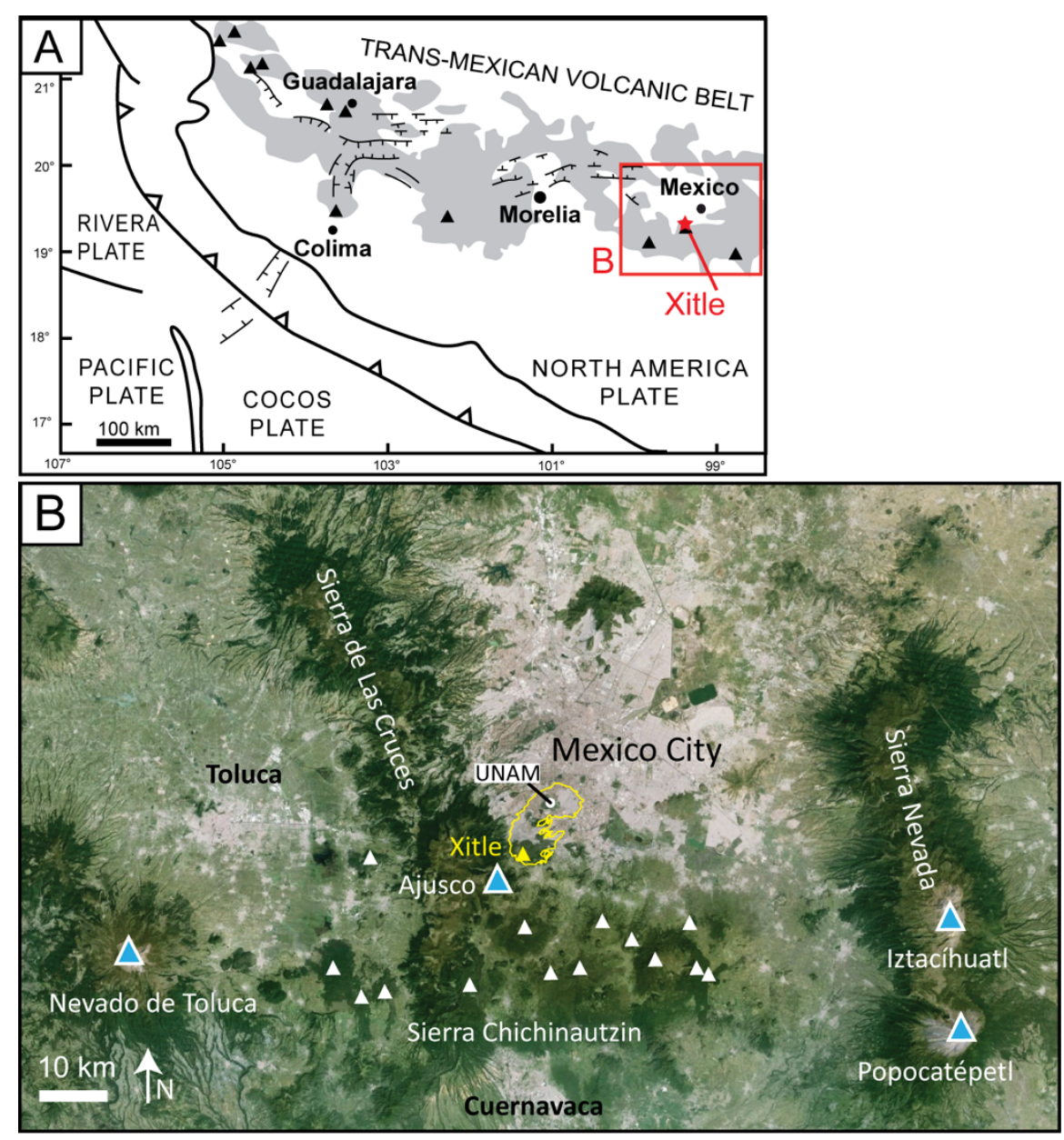

980 Fig. 1 A. Localization of the Xitle volcano and Mexico City in the Trans-Mexican Volcanic

981 Belt and associated arc-type tectonic system. Dark filled triangles indicate mayor

982 stratovolcanoes along the belt. Black filled points indicate main cities with millions of

983 inhabitants. Note that most of these are located in the volcanic belt and hence at risks from

984 new and ongoing eruptions. B. Localization of Xitle volcano (yellow triangle) and Xitle lava

985 field (yellow polygon) including the UNAM campus, in the SW corner of the Mexico Basin

986 host to Mexico City. White triangles are volcanoes of the Sierra Chichinautzin formed during

987 the last 15,000 yrs. Blue and white triangles are stratovolcanoes. Popocatepetl is in eruption

988 since 1994, while the Nevado de Toluca last erupted 10,000 yrs ago. Ajusco is extinct 


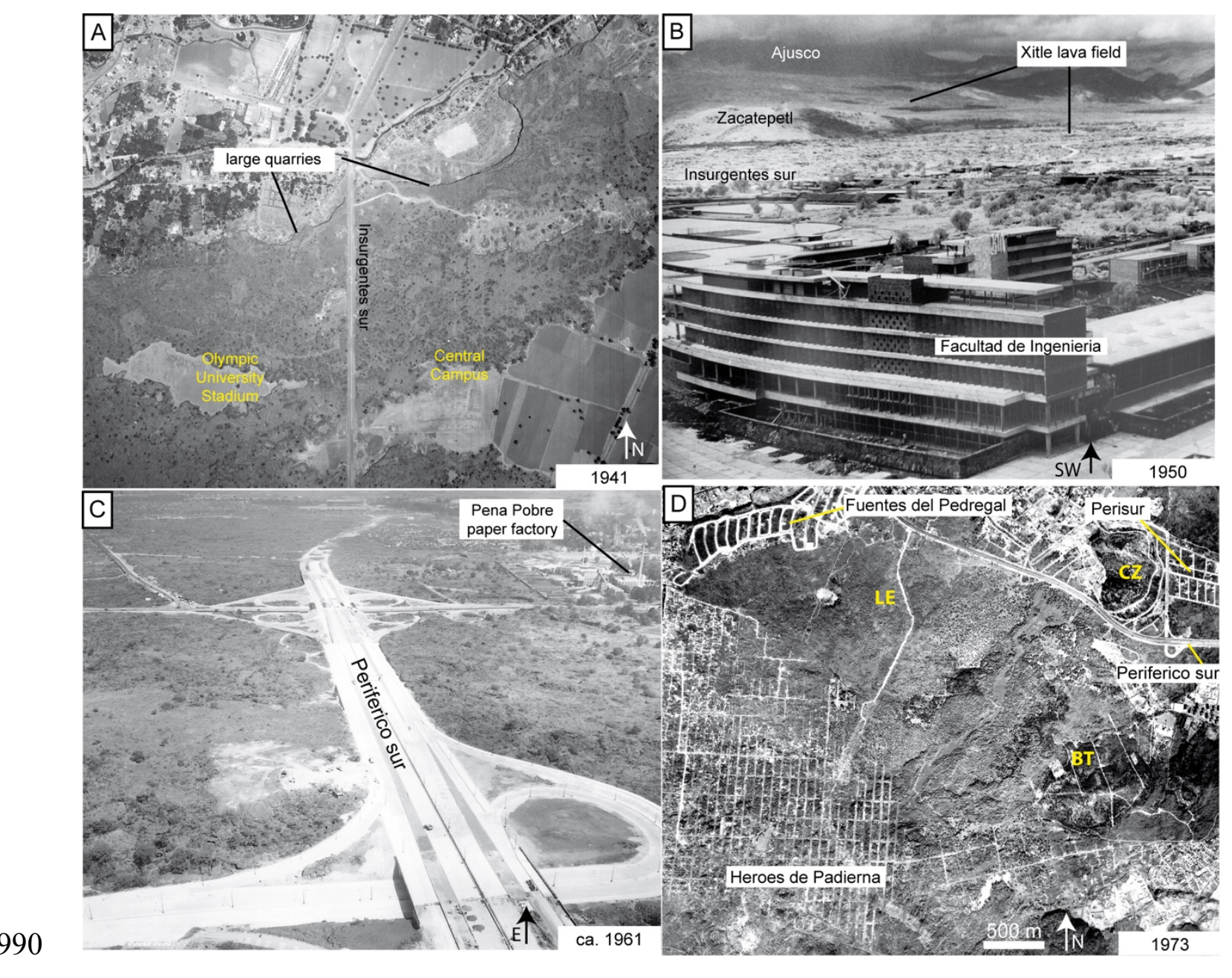

991 Fig. 2 A. Vertical aerial photo of the present location of the central part of the UNAM campus

992 in 1941 (FICA foundation). The location of the agricultural fields where the Olympic

993 University stadium and the Central Campus were constructed few years later is indicated.

994 Note also the concave shape of large quarries into the lavas that are now urbanized. The entire

995 area is virtually unrecognizable in today's photographs. B. Oblique aerial photo of the first

996 university building constructed over the lava field (taken from Salas Portugal, 2006). C.

997 Oblique aerial photo of the southern peripheric road of Mexico City (Periferico sur), just after

998 its construction on the lavas in 1961 (provided by A. Lentz). D. Vertical aerial photo of the

999 lava field to the south of the Periferico sur in 1973. Note the road tracks of an exclusive

1000 residential area (Fuentes del Pedregal) and a mall (Perisur) in the northern part, and a more 
1001 extensive popular area (Heroes de Padierna) to the southeast. The area is now entirely

1002 urbanized, except for few remaining patches including the Los Encinos area (LE), the summit

1003 of Cerro Zacatepetl hill (CZ), and the Bosque de Tlalpan (BT)

1004
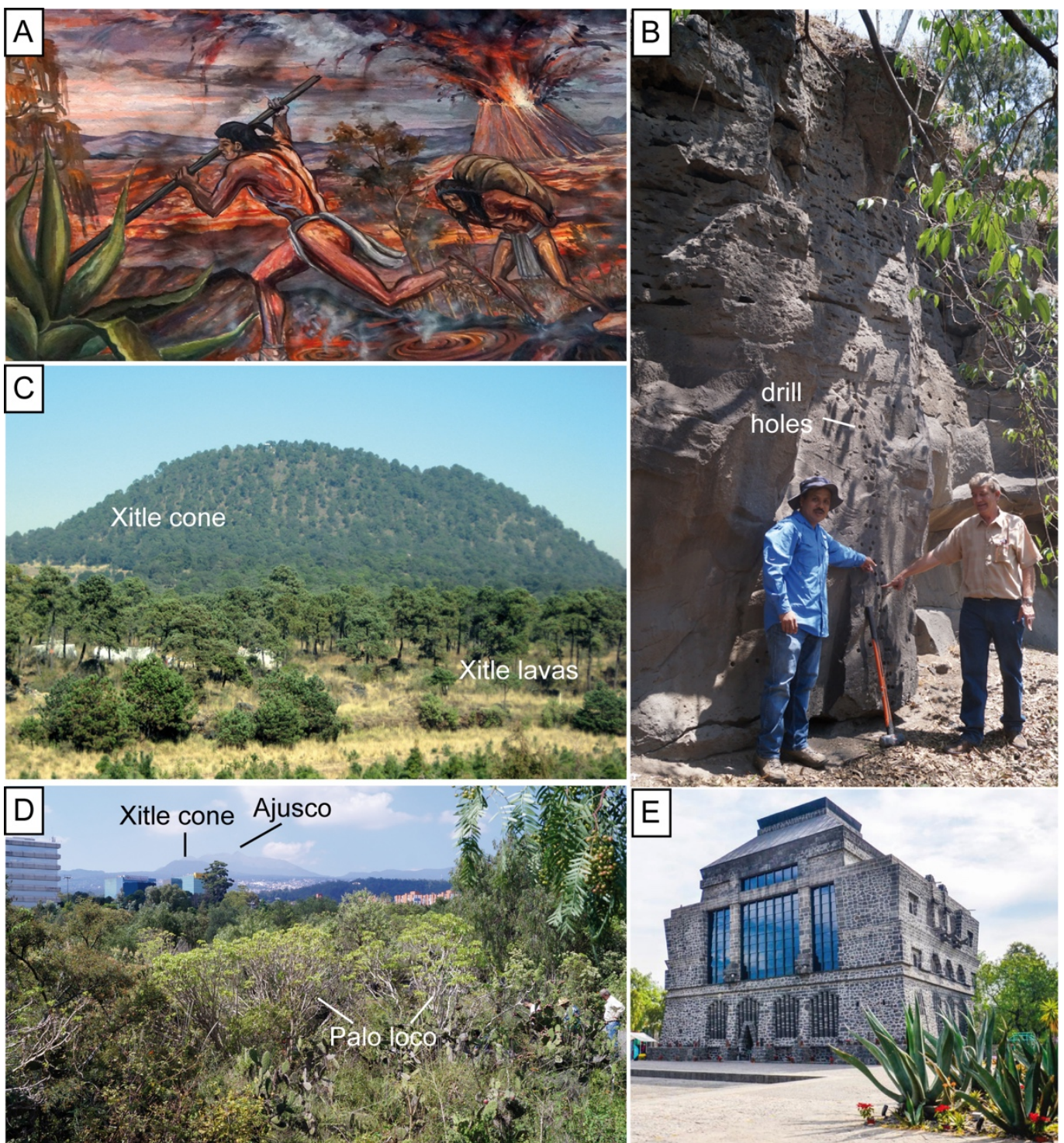

1006 Fig. 3 A. Detail of a painting on the facade of the town hall building of Tlalpán featuring pre-

1007 hispanic people fleeing the Xitle eruption. B. Photograph of a vertical cut into a sheet lobe

1008 along the Insurgentes avenue in UNAM. Men point to a vertical line of holes drilled for

1009 paleomagnetism studies. C. Photograph of the Xitle cone and proximal lavas covered by a 
1010 pine tree forest, from the south. D. Photograph of the vegetated lava flow preserved in the

1011 Cuicuilco archaeological site. Note the Xitle cone and Ajusco stratovolcano in the distance.

1012 E. Photograph of the Anahuacalli museum built by Diego Rivera to expose its collection of

1013 archaeologic pieces. It is made entirely by stones from the Xitle lava and preserves a patch

1014 of the lava field around it

1015

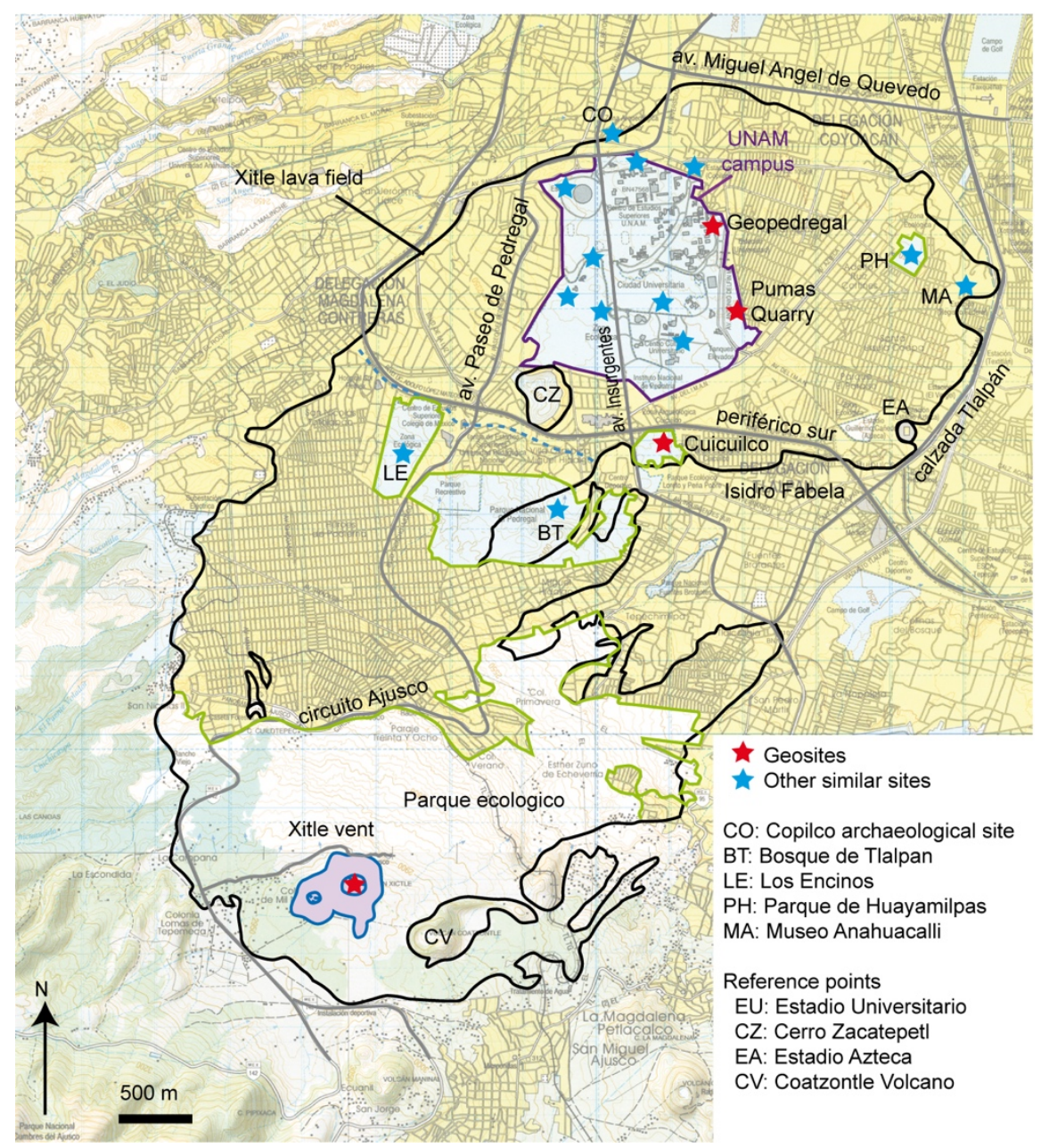

1017 Fig. 4 General map of the Xitle cone and lava flow field with the location of important

1018 reference points in the city and the sites described in the text. Note that the topographic map

1019 used as background indicate in yellow the constructed areas, while "natural" areas are left in 
1020 white. Most of these correspond to places where the lava surface and its vegetation can still

1021 be observed, although illegal settlements are commonly found and deteriorate the sites

1022
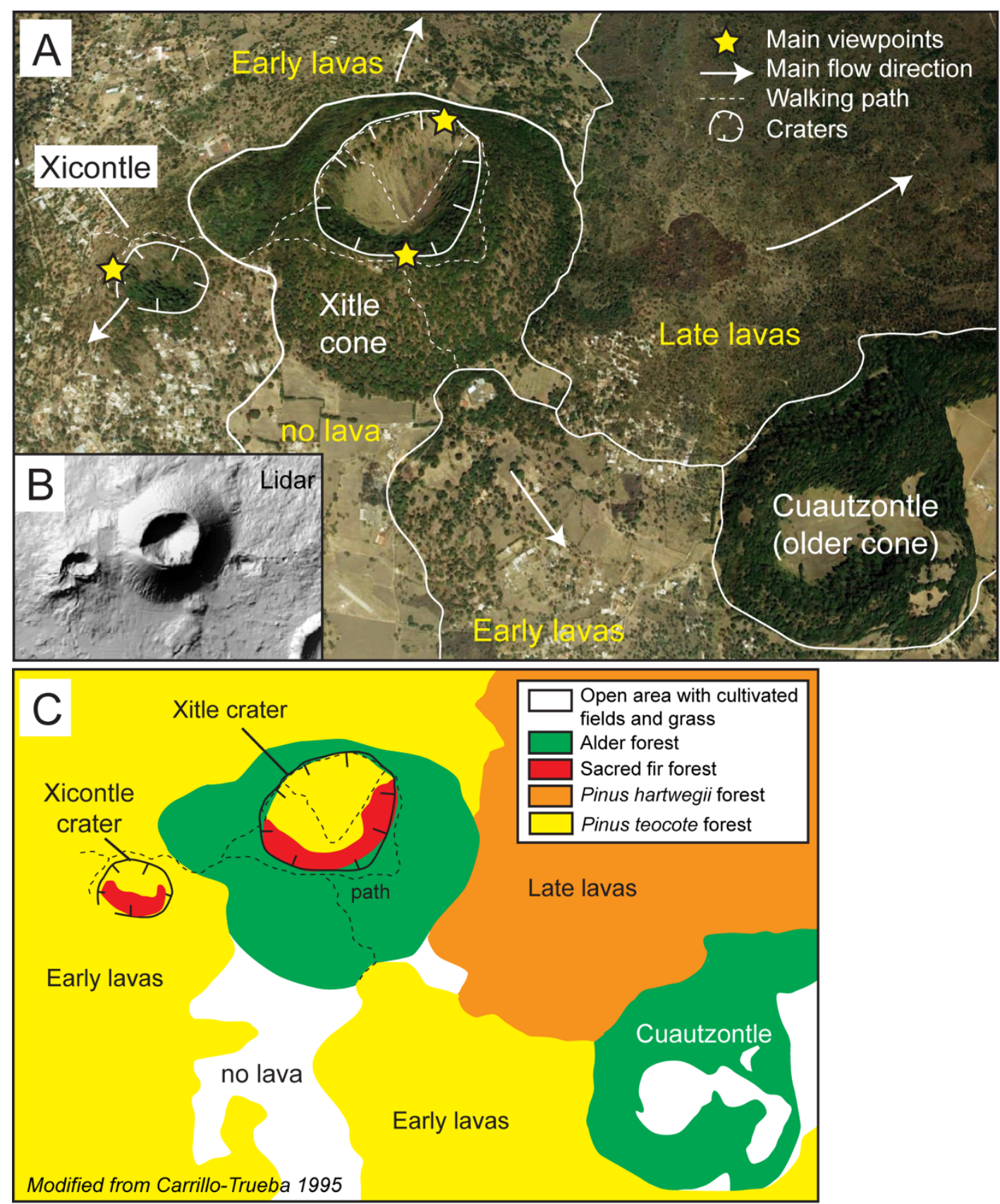

1024 Fig. 5 Vent area geosite: Maps. A. Cartography of main volcanic elements along with the

1025 walking paths and location of early- and late-formed lavas on a slightly-inclined view of 
1026 satellite images draped over an elevation model from Google Earth. B. Shaded relief from a

10275 -m resolution digital elevation model that shows clearly the shape and inner crater of the

1028 main scoria cone and the Xicontle spatter-lava cone. C. Vegetation cover map modified from

1029 Carrillo-Trueba (1995), and drawn from satellite images and field observations. See the text

1030 for more explanation

1031

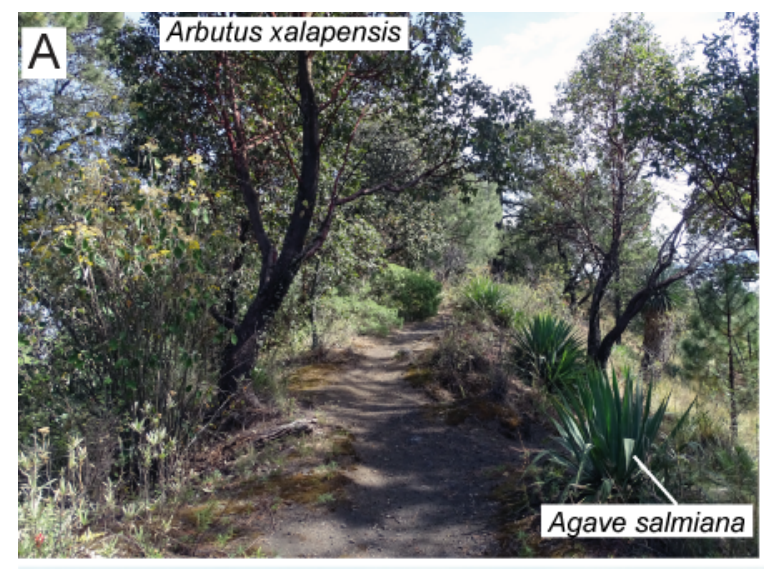

B
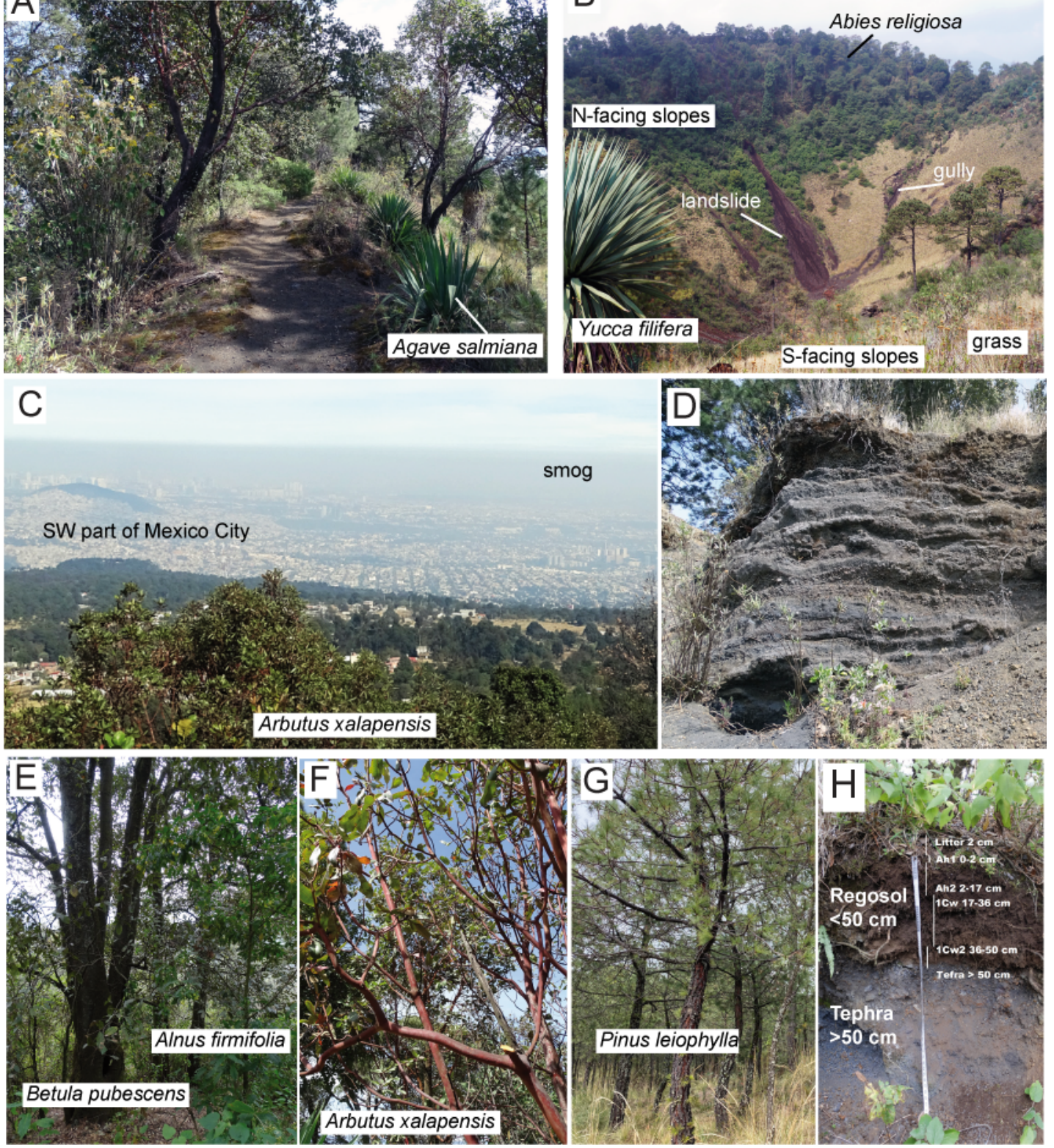
1033 Fig. 6 Vent area geosite: Pictures. A. Photograph showing the path surrounding the crater 1034 rim of the Xitle cone on its west side and the associated vegetation pattern. B. Photograph 1035 taken from the south part of the crater rim, looking north, showing the $\mathrm{N}$ - and S-facing crater 1036 slopes and their contrast in vegetation and erosional pattern. C. Photograph on the view from 1037 the southern part of the Xitle crater rim looking N, showing the southern part of Mexico City 1038 covered by smog. D. Photograph of a ca. $1 \mathrm{~m}$ deep exposure into the outermost layers of the

1039 Xitle cone that consist of layers of tephra, from ash to lapilli in size. E, F, G. Photographs of

1040 important tree species on the Xitle cone. H. Photograph of the soil section described in detail 1041 in Table 2 and in the text

1042 

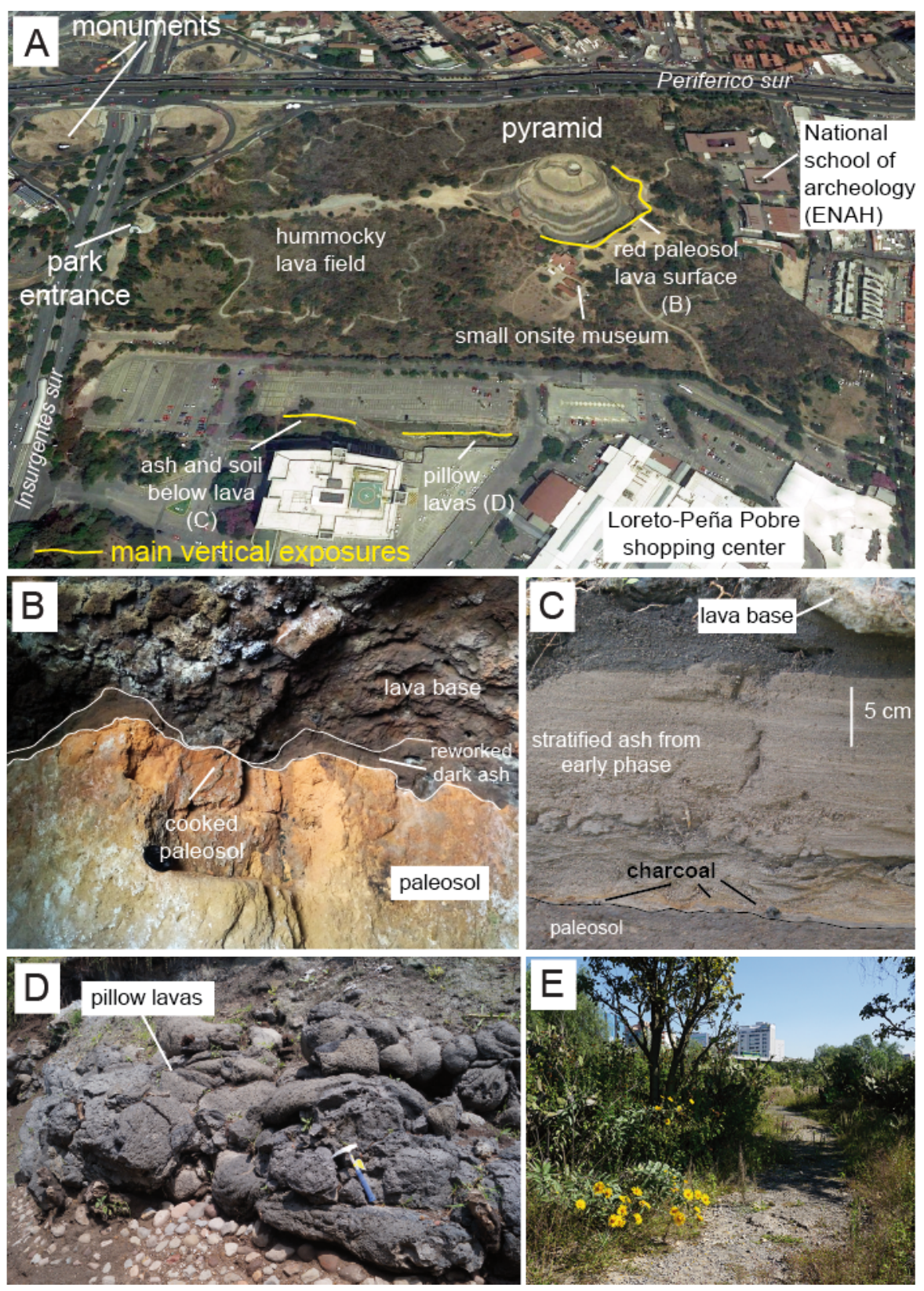

1044 Fig. 7 Cuilcuilco geosite. A. Cartography of main anthropic, archeologic and volcanic

1045 elements on a slightly-inclined view of satellite images draped over an elevation model from

1046 Google Earth. Capital letters indicate the location where the subsequent pictures were taken.

1047 B. Photograph taken inside the tunnel excavated below the lavas, that shows the paleosol,

1048 ash layer and lava base. C. Photograph of a finely stratified, 17-cm-thick ash layer found just

1049 below the lava, at an outcrop located next to a building in the commercial center. Note the 
1050 tiny dark charcoal bits found in the lowermost ash layer. Similar fragments were dated using

1051 radiocarbon by Siebe (2000) to obtain the age of the eruption. D. Rounded pillow-type lavas

1052 exposed along the ground level of a carpark in the commercial center. Archeologists obtained

1053 the permission in late 2018 to study this area in details because of the imminent occurrence

1054 of major building works. E. Photograph taken at the start of one of the pedestrian paths that

1055 cross the lava field surrounding the pyramid. Note the pleasantness of the path provided by

1056 the vegetation and the slightly irregular ground. One of the tall buildings constructed along

1057 the "Periferico Sur" avenue is visible in the background, highlighting the close vicinity of

1058 one of the busiest roads in Mexico City. 

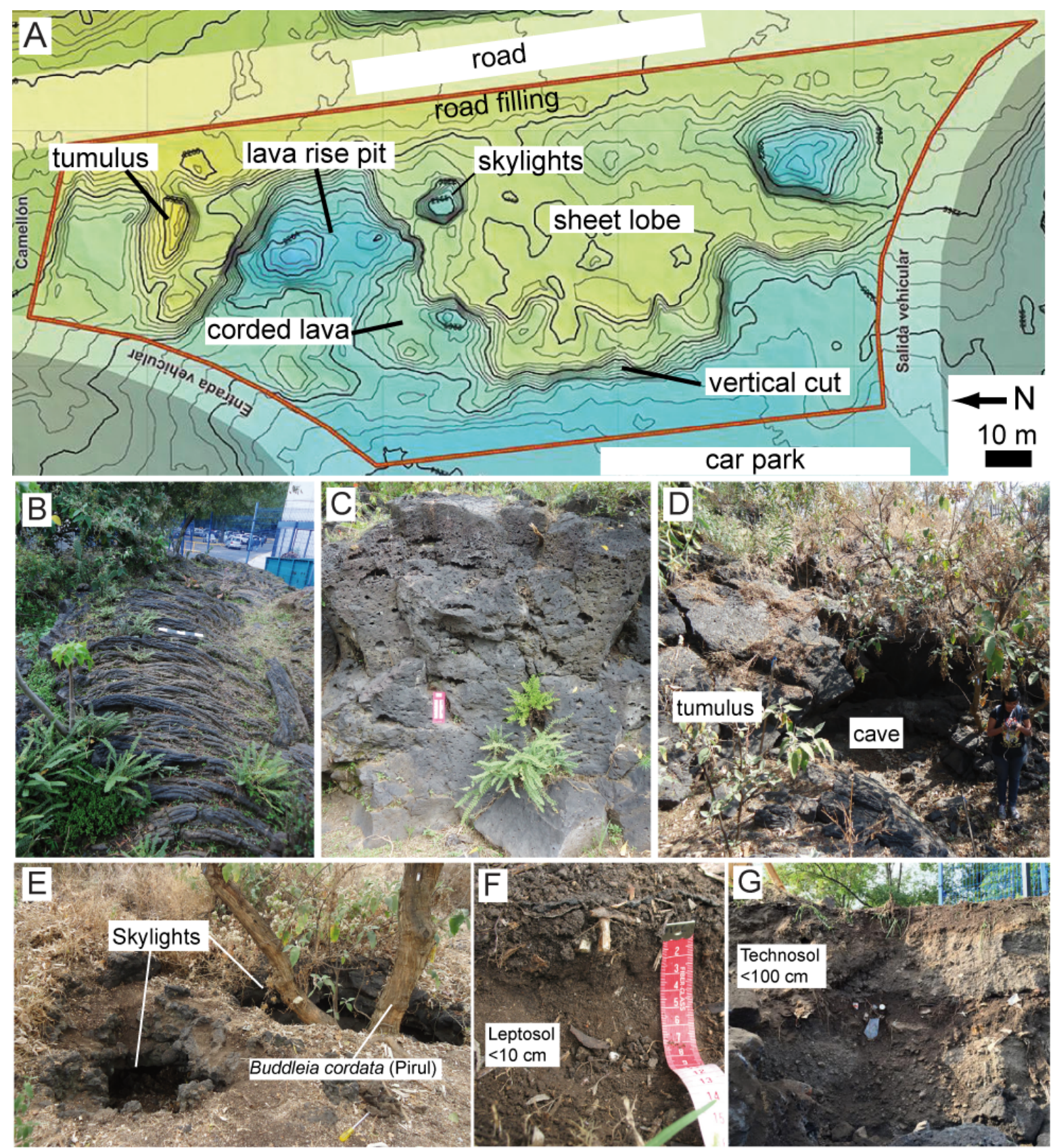

1060 Fig. 8 Geopedregal geosite. A. Topographic map showing the distinct volcanological

1061 elements described in the text. Adapted from figure made by P. Leautaud. B. Photograph of

1062 the corded lava features. C. Photograph of the vertical section across the lava that displays

1063 the typical upward increase in vesicle density and decrease in vesicle size that is observed in

1064 pahoehoe lavas and is symptomatic of a growth by inflation. Note also the vegetation growing 
1065 in the small fractures (cooling joints) in the lava. D. Photograph of the oval-shaped tumulus 1066 that borders the site and present a lateral cave that is occupied by bats and other local fauna.

1067 E. Photograph of the jointed skylights that formed on the sheet lobe. Note the relatively large

1068 Tepozán tree that grew from inside the cavity. F. Photograph of the typical type of soil that

1069 forms locally on the lava (see text and Table 2 for description). G. Photograph of the

1070 anthropogenic Technosol soil observed on top of the lava, along the road. Note the 1071 occurrence of man-made objects within the soil (mostly made of plastic) and gravel 

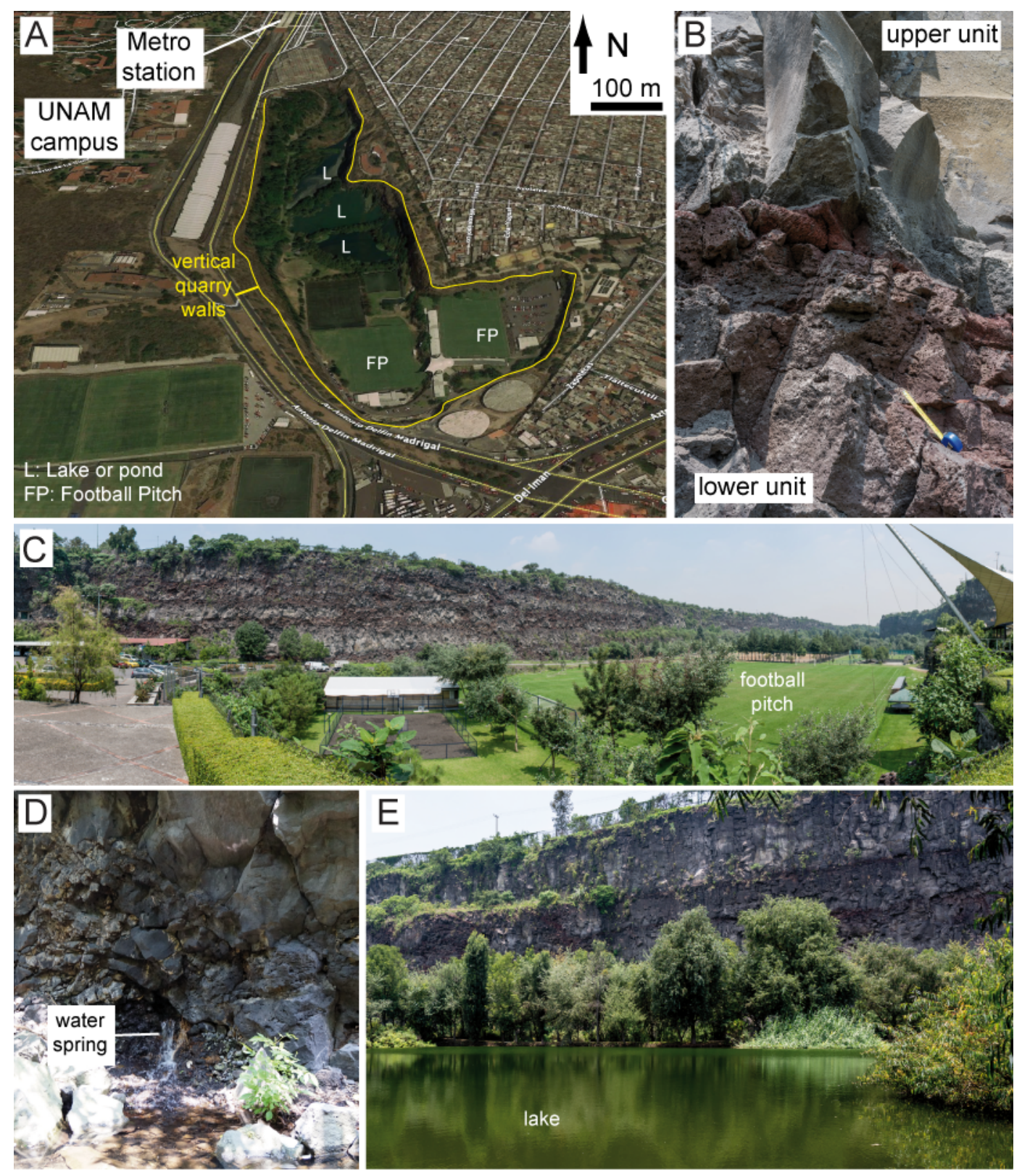

1073 Fig. 9 Pumas quarry geosite. A. Map of the Pumas quarry or Cantera Poniente. Note its

1074 location between the UNAM campus to the west, and the densely-populated Santo Domingo

1075 popular borrow to the east. B. Contact between two flow units exposed along the quarry

1076 walls. Note the reddish (oxidized) vesicular upper crust of the lower unit and denser, light-

1077 gray internal core of the upper unit. C. Panoramic photograph of the site that shows the largest

1078 football pitch and the quarry walls, as well as the surrounding green areas. D. Photograph of 
1079 a water spring that can be seen along a walking path at the base of the highest quarry wall 1080 along the western border of the site. E. Photograph of the lake and the eastern quarry wall in 1081 the background, taken from a walking path. Note the pleasant green setting and peculiar 1082 vegetation

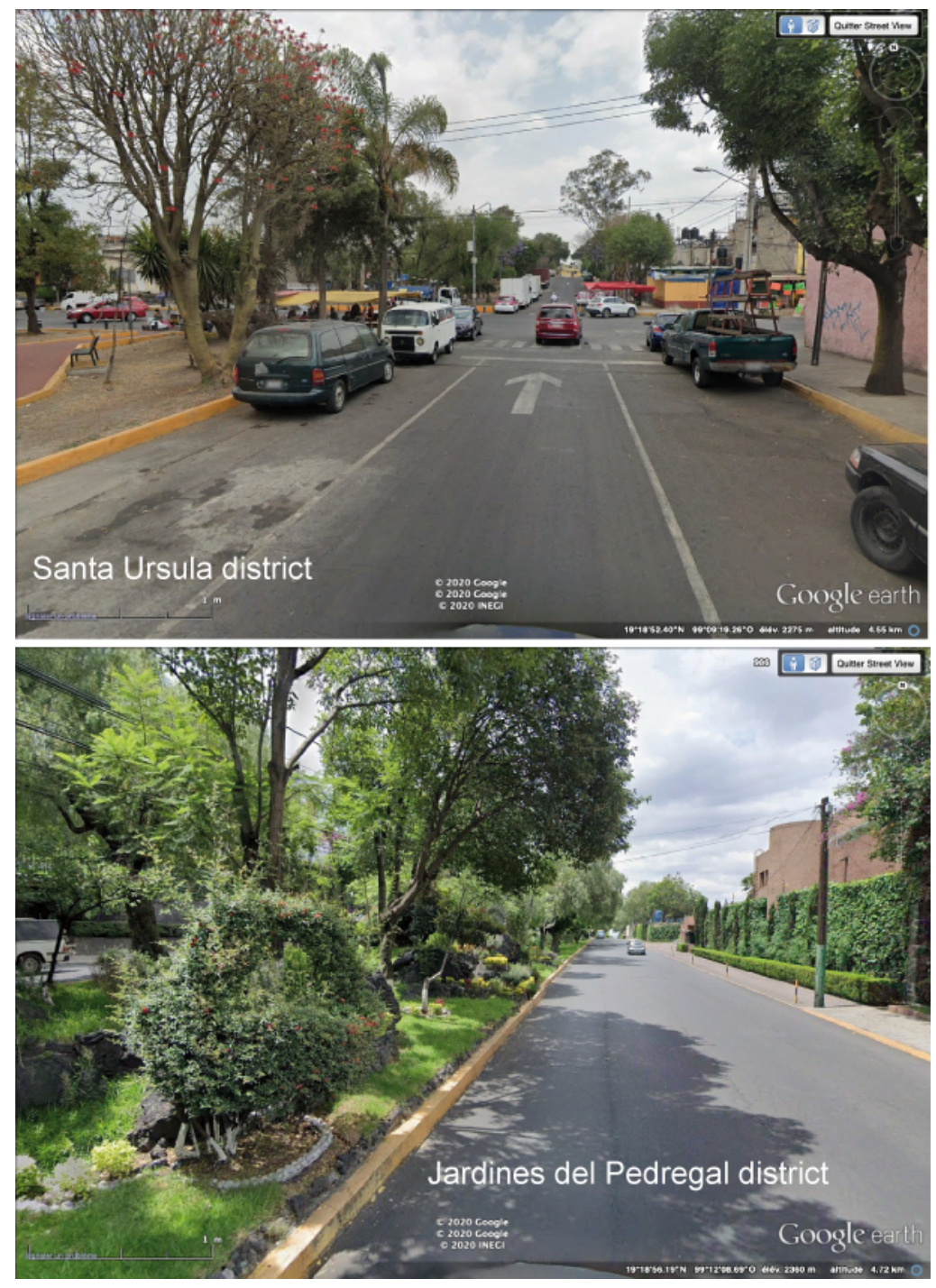

1084 Fig. 10 Pictures taken using google street view, of two districts, a poor (Santa Ursula) and a 1085 rich (Jardines del Pedregal) constructed over the Xitle lava field. Note the differences in the 1086 environment (see text for more details). 


\section{References}

1089 Aguilar AG, Santos C (2011) Informal settlements' needs and environmental conservation 1090 in Mexico City: An unsolved challenge for land-use policy. Land Use Policy 28(4): 49$1091 \quad$ 662. https://doi.org/10.1016/j.landusepol.2010.11.002

1092 Agustín-Flores J, Siebe C, Guilbaud MN (2011) Geology and geochemistry of Pelagatos, 1093 Cerro del Agua, and Dos Cerros monogenetic volcanoes in the Sierra Chichinautzin 1094 Volcanic Field, south of México City, J Volcanol Geoth Res 201:143-162. DOI: $1095 \quad$ 10.1016/j.jvolgeores.2010.08.010

1096 Alva-Valdivia LM (2005). Comprehensive paleomagnetic study of a succession of Holocene 1097 olivine-basalt flow: Xitle Volcano (Mexico) revisited. Earth planets and space 57(9): $1098 \quad 839-853$

1099 Aragón-Durand F (2007) Urbanisation and flood vulnerability in the peri-urban interface of 1100 Mexico City. Disasters 31(4):477-494. https://doi.org/10.1111/j.1467$1101 \quad$ 7717.2007.01020.x

1102 Arce JL, Layer PW, Lassiter JC, Benowitz JA, Macías JL, Ramírez-Espinosa J (2013) 1103 40Ar/39Ar dating, geochemistry, and isotopic analyses of the quaternary Chichinautzin 1104 volcanic field, south of Mexico City: implications for timing, eruption rate, and 1105 distribution of volcanism. Bull Volcanol 75:774

1106 Arce JL, Muñoz-Salinas E, Castillo M, Salinas I (2015) The 2000 yr BP Jumento volcano, 1107 one of the youngest edifices of the Chichinautzin Volcanic Field, Central Mexico. J $1108 \quad$ Volcanol Geoth Res 308:30-38

1109 Arnold JR, Libby WF (1951) Radiocarbon dates. Science 113(2927):111-120 
1110 Badilla-Cruz RR (1977) Estudio petrológico de la lava de la parte noreste del Pedregal de

1111 San Ángel, D.F. Bol Soc Geol Mex 38:40-57

1112 Bloomfield K (1975) A late-Quaternary monogenetic volcano field in central Mexico. Geol

$1113 \quad$ Rundsch 64:476-497

1114 Bonilla-Aldana DK, Dhama K, Rodriguez-Morales AJ (2020) Revisiting the one health 1115 approach in the context of COVID-19: a look into the ecology of this emerging disease. $1116 \quad$ Adv Anim Vet Sci, 8(3), 234-237.

1117 Boothroyd A, McHenry M (2019) Old processes, new movements: the inclusion of 1118 geodiversity in biological and ecological discourse. Diversity 11(11):216. 1119 https://doi.org/10.3390/d11110216

1120 Brilha J (2016) Inventory and Quantitative Assessment of Geosites and Geodiversity Sites: 1121 a Review. Geoheritage 8(2):119-134. doi: 10.1007/s12371-014-0139-3

1122 Brilha J, Gray M, Pereira D I, Pereira P (2018) Geodiversity: An integrative review as a 1123 contribution to the sustainable management of the whole of nature. Environ Sci Policy $1124 \quad 86: 19-28$

1125 Camarena-Berruecos P (2010) Xerojardinería. Guía para el diseño de los jardines de Ciudad 1126 Universitaria. Universidad Nacional Autónoma de México, Mexico City, 92 pp

1127 Campillo M, Gariel JC, Aki K, Sánchez-Sesma FJ (1989) Destructive strong ground motion 1128 in Mexico City: Source, path, and site effects during great 1985 Michoacán earthquake. $1129 \quad$ Bull Seismol Soc Am 79(6):1718-1735

1130 Cano-Santana Z, Pisanty I, Segura S, Mendoza-Hernández PE, León-Rico R, Soberón J, et 1131 al (2006) Ecología, conservación, restauración y manejo de las áreas naturales y 1132 protegidas del Pedregal del Xitle. In : Oyama K, Castillo A (eds) Manejo, conservación 
1133 y Restauración de Recursos naturales en México, UNAM-Siglo XXI, Mexico City, pp $1134 \quad 203-226$

1135 Canteiro M, Olea S, Escolero O, Zambrano L (2019) Relationships between urban aquifers 1136 and preserved areas South of Mexico City. Groundw Sustain Dev 8:373-380

1137 Cañon-Tapia E, Walker GPL, Herrero-Bervera E (1995) Magnetic fabric and flow direction 1138 in basaltic Pahoehoe lava of Xitle Volcano, Mexico: J Volcanol Geotherm Res 65:249$1139 \quad 263$

1140 Cañon-Tapia E, Walker GPL, Herrero-Bervera E (1996). The internal structure of lava flows1141 insights from AMS measurements I: Near-vent aa: J Volcanol Geotherm Res 70:21-36 1142 Carrillo-Trueba C (1995) El Pedregal de San Ángel, Universidad National Autonoma de $1143 \quad$ Mexico, Mexico City

1144 Castellanos-Vargas I, García-Calderón NE, Cano Santana Z (2017) Procesos físicos del suelo 1145 en la reserva ecológica del Pedregal de San Ángel de Ciudad Universitaria: atributos 1146 para su conservación. Terra Latinoamericana 35(1):51-64

1147 Clivaz M, Reynard E (2018) How to integrate invisible geomorphosites in an inventory: A 1148 case study in the Rhone River valley (Switzerland). Geoheritage 10(4) :527-541

1149 Coordinación de Proyectos Especiales, UNAM (2005) Technical file for the nomination of 1150 campus central de la Ciudad Universitaria de la UNAM for the Inscription in the $1151 \quad$ Unesco World Heritage List, Mexico City.

1152 Córdova C, Martin del Pozzo AL, Camacho JL (1994) Palaeolandforms and Volcanic Impact 1153 on the Environment of Prehistoric Cuicuilco, Southern Mexico City. J Archaeol Sci $1154 \quad 21(5): 585-596$

1155 Cummings B (1926) Cuicuilco and the Archaic culture of Mexico: Scientific Monthly, $1156 \quad 23: 289-304$ 
1157 Del Monte M, Fredi P, Pica A, Vergari F (2013) Geosites within Rome City center (Italy): a

1158 mixture of cultural and geomorphological heritage. Geografia Fisica e Dinamica 1159 Quaternaria 36(2):241-257

1160 Del Moral R, Grishin SY (1999) Volcanic disturbances and ecosystem recovery. In: Walker

1161 LR (Ed) Ecosystems of disturbed Ground, Elsevier, Amsterdam, pp 137-160

1162 Delgado H, Molinero R, Cervantes P, Nieto-Obregón J, Lozano-Santa Cruz R, Macías-

1163 González HL, Mendoza-Rosales C, Silva-Romo G (1998) Geology of Xitle volcano in

1164 southern Mexico-City, A 2000 year-old monogenetic volcano in an urban area. Revista

1165 Mexicana de Ciencias Geológicas 15 (2):115-131

1166 Eakin H, Lerner AM, Manuel-Navarrete D, Aguilar BH, Martínez-Canedo A, Tellman B,

1167 Bojórquez-Tapia L (2016) Adapting to risk and perpetuating poverty: household's

1168 strategies for managing flood risk and water scarcity in Mexico City. Environ Sci

$1169 \quad$ Policy 66:324-333

1170 Eiser JR, Bostron A, Bruton I, Johnston DM, McClure J, Paton D, van de Pligt J, White MP

1171 (2012) Risk interpretation and action: A conceptual framework for responses to natural

1172 hazards. Intern J Disaster Risk Reduction 1:5-16

1173 Estañol-Tecuatl F, Cano-Santana Z (2017) Recovery of basalt substrate for xeric scrub

1174 restoration in a lava field in Mexico City. Ecological Restoration 35(1):41-51.

1175 Fassoulas C, Watanabe M, Pavlova I, Amorfini A, Dellarole E, Dierickx F (2018) UNESCO

1176 Global Geoparks: living laboratories to mitigate natural induced disasters and 1177 strengthen communities' resilience. In : Antronico L, Marincioni F (Ed) Natural 1178 Hazards and Disaster Risk Reduction Policies, Geographies of the Anthropocene, pp $1179 \quad 175-285$ 
1180 Flores-Estrella H, Yussim S, Lomnitz C (2007) Seismic response of the Mexico City Basin:

1181 A review of twenty years of research. Natural Hazards 40(2):357-372.

$1182 \quad$ https://doi.org/10.1007/s11069-006-0034-6

1183 Gamio M (1920) Las excavaciones del Pedregal de San Angel y la cultura arcaica del Valle

1184 de México. American Anthropologist 22(2):127-143

1185 GDF (Gobierno del Distrito Federal) (2012) Atlas geográfico del suelo de conservación del

1186 Distrito Federal. Secretaría del Medio Ambiente, Procuraduría Ambiental y del

1187 Ordenamiento Territorial del Distrito Federal, México, D.F.

1188 González R, Estrada M, Orellana A, Bueno I, Segura S (2016) Saving Islands Within a City.

1189 Available online at: https://it.cornell.edu/ (accessed March 17, 2019)

1190 González S, Pastrana A, Siebe C, Duller G (2000) Timing of the prehistoric eruption of Xitle

1191 Volcano and the abandonment of Cuicuilco Pyramid, Southern Basin of Mexico. In:

1192 McGuire et al (Eds) The archaeology of geological catastrophes, Geological Society,

1193 London, Special publications 171:205-224

1194 Gordon JE, Crofts R, Díaz-Martínez E (2018) Geoheritage conservation and environmental

1195 policies: retrospect and prospect. In: Brilha J, Reynard E (eds) Geoheritage

1196 Assessment, Protection and Management, Elsevier, Amsterdam, Chapter 12, pp 213-

$1197 \quad 235$

1198 Górska-Zabielska M, Zabielski R (2017) Potential values of urban geotourism development

1199 in a small Polish town (Pruszków, Central Mazovia, Poland). Quaestiones

$1200 \quad$ Geographicae 36(3):75-86

1201 Gray M (2013) Geodiversity: Valuing and Conserving Abiotic Nature, 2nd Edition, Wiley,

1202 Blackwell. ISBN: 978-0-470-74215-0 
1203 Gray M (2018) Geodiversity: the backbone of geoheritage and geoconservation. In : Brilha

1204 J, Reynard E (Eds) Geoheritage Assessment, Protection and Management, Elsevier,

1205 Amsterdam, pp 13-25. https://doi.org/10.1016/B978-0-12-809531-7.00001-0

1206 Guilbaud MN, Arana-Salinas L, Siebe C, Barba-Pingarrón LA, Ortiz A (2015) Volcanic

1207 stratigraphy of a high-altitude Mammuthus columbi (Tlacotenco, Sierra

1208 Chichinautzin), Central México. Bull Volcanol 77:17. DOI:10.1007/s00445-015-0903-

$1209 \quad 5$

1210 Guilbaud MN, Siebe C (2009) The lava flow-field of the ca. 1670 yrs BP Xitle eruption,

1211 México: structure and implications for eruption dynamics (abstract). In : Siebe C,

1212 Guilbaud M-N, Salinas S (Eds) 250 Aniversario del nacimiento del volcán Jorullo en

1213 México: Morelia, Michoacán, Mexico. Impretei, Mexico City, pp 28-29

1214 Hardoy J, Mitlin D, Satterthwaite D (2013) Environmental problems in an urbanizing world:

1215 finding solutions in cities in Africa, Asia and Latin America. Earthscan Publications

1216 Ltd, London, Washington DC.

1217 Heizer R, Bennyhoff JA (1958) Archaeological investigations of Cuicuilco, Valley of

$1218 \quad$ Mexico, 1956. Science 127:232-233

1219 Heizer R, Bennyhoff JA (1972) Archaeological excavations at Cuicuilco, Mexico, 1957. Nat

$1220 \quad$ Geog Rep 1955-1960 :93-104

1221 Hernández-Robles HE (2019) Dinámica de cambio de uso de suelo y coberturas vegetales en

1222 el derrame de lava del volcán Xitle, Ciudad de México, 1993-2015. Undergraduate

1223 thesis, Facultad de Ciencias, UNAM 
1224 Hon K, Kauahikaua J, Denlinger R, Mackay K (1994) Emplacement and inflation of 1225 pahoehoe sheet flows, Observations and measurements of active lava flows on Kilauea 1226 Volcano, Hawaii. Geol Soc Am Bull 106:351-370

1227 Hough M (2004) Cities and natural process. Routledge, London and New York

1228 Hubp J, Inbar M, Pastrana A, Flores A, Zamorano J (2001). Interpretation of the geomorphic 1229 setting of the Cuicuilco basin, Mexico City, affected by the pre-Hispanic eruption of 1230 the Xitle volcano/Interprétation de l'environnement géomorphologique du bassin de 1231 Cuicuilco, ville de Mexico, affecté par l'éruption pré-hispanique du volcan Xitle. 1232 Géomorphologie: relief, processus, environnement 7(3) :223-232

1233 Jim CY (2004) Green-space preservation and allocation for sustainable greening of compact $1234 \quad$ cities. Cities 21(4):311-320

1235 Jim CY (2013) Sustainable urban greening strategies for compact cities in developing and 1236 developed economies. Urban Ecosyst 16(4):741-761

1237 Kelly J (1982) The Complete Visitor's Guide to Mesoamerican Ruins. University of $1238 \quad$ Oklahoma Press

1239 Keszthelyi L (1995) A preliminary thermal budget for lava tubes on the Earth and planets. J 1240 Geophys Res: Solid Earth, 100(B10): 20411-20420.

1241 Krieger P (2008) Lecciones inesperadas de Ciudad Universitaria y su reserva ecológica. $1242 \quad$ Bitácora Universitaria 18:46-49

1243 López-Valdés N (2019) Secuencia de eventos eruptivos recientes en el sector oriental de la 1244 Sierra Chichinautzin, Centro de México: Distribución, edad y composición química de 1245 lavas y tefras. Master thesis, UNAM, Mexico 
1246 Lorenzo-Merino L, Guilbaud MN, Roberge J (2018) The violent-Strombolian eruption of 10

1247 ka Pelado shield volcano, Sierra Chichinautzin, Central Mexico, Bull Volc 80:27.

$1248 \quad$ https://doi.org/10.1007/s00445-018-1208-2

1249 Lot A (2007) Guía ilustrada de la Cantera Oriente. Caracterización ambiental e inventario 1250 biológico. Coordinacion de la Investigacion Cientifica, Universidad Nacional $1251 \quad$ Autonoma de Mexico, Mexico City

1252 Lot A, Cano-Santana Z (2009) Biodiversidad del ecosistema del Pedregal de San Ángel.

$1253 \quad$ Universidad Nacional Autónoma de México, Mexico City

1254 Luhr JF, Simkin T (1993) Parícutin: the volcano born in a Mexican cornfield. US Geoscience $1255 \quad$ Press Phoenix

1256 Mancebo F (2007) Natural hazards and urban policies in Mexico City. Journal of Alpine 1257 Research. Revue de géographie alpine (95-2):108-118

1258 Márquez A, Verma SP, Anguita F, Oyarzun R, Brandle JL (1999) Tectonics and volcanism

1259 of Sierra Chichinautzin: extension at the front of the Central Trans-Mexican Volcanic 1260 belt. J Volcanol Geotherm Res 93(1-2):125-150

1261 Martín del Pozzo, AL (1982) Monogenetic volcanism in Sierra Chichinautzin, Mexico. Bull $1262 \quad$ Volcanol 451-24

1263 McKeever PJ, Zouros N (2005). Geoparks: Celebrating Earth heritage, sustaining local $1264 \quad$ communities. Epis 28(4):274

1265 Nistor C, Mihai B, Toma L, Carlan I (2017) Photogrammetric modelling for urban medieval 1266 site mapping. A case study from Curtea de Argeş, Romania. Quaestiones 1267 Geographicae 36(3):87-96 
1268 Ortiz-Zamora D, Ortega-Guerrero A (2010) Evolution of long-term land subsidence near 1269 Mexico City: Review, field investigations, and predictive simulations. W Resour Res 1270 46(1):W01513. https://doi.org/10.1029/2008WR007398

1271 Palacio JL, Guilbaud MN (2015) Patrimonio natural de la Reserva Ecológica del Pedregal de 1272 San Ángel y áreas cercanas: sitios de interés geológico y geomorfológico al sur de la 1273 Cuenca de México. Bol Soc Geol Mex 67(2):227-244

1274 Parsons JR (1989) Arqueología regional en la Cuenca de México: una estrategia para la 1275 investigación futura. Anales de Antropología 26:1

1276 Pavlova I (2019) Disaster risk reduction at UNESCO Global Geoparks and Biosphere 1277 Reserves. Journal of World Heritage Studies, Special issue 2019, p 73-77 $1278 \quad$ http://doi.org/10.15068/00157689

1279 Peña-Ramírez VM, Vázquez-Selem L, Siebe C (2009) Soil organic carbon stocks and forest 1280 productivity in volcanic ash soils of different age (1835-30,500 years BP) in Mexico. $1281 \quad$ Geoderma 149(3-4):224-234

1282 Pérez-Galicia A, Pérez-Campuzano E (2015) La complejidad del manejo de zonas de turismo 1283 (eco) arqueológico en ciudades. El caso de Cuicuilco, México. Pasos, Revista de 1284 turismo y patrimonio cultural. $13 \quad$ (5):1079-1094. $1285 \quad$ https://doi.org/10.25145/j.pasos.2015.13.074

1286 Pérez-Méndez A (2007) Las casas del Pedregal. Editorial Gustavo Gili, Mexico City, 323 p 1287 Peterson FL (1972) Water development on tropic Volcanic Islands-Type example: Hawaii 1288 a. Groundw 10(5):18-23

1289 Petrosino P, Iavarone R, Alberico I (2019) Enhancing Social Resilience Through Fruition of 1290 Geological Heritage in the Vesuvio National Park. Geoheritage 11:2005-2024. $1291 \quad$ https://doi.org/10.1007/s12371-019-00404-y 
1292 Pezzoli K (2000) Human settlements and planning for ecological sustainability: the case of $1293 \quad$ Mexico City. MIT press

1294 Pica A, Vergari F, Fredi P, Del Monte M (2016) The aeterna urbs geomorphological heritage

1295 (Rome, Italy). Geoheritage 8(1):31-42

1296 Pica A, Luberti GM, Vergari F, Fredi P, Del Monte M (2017) Contribution for an urban 1297 geomorphoheritage assessment method: proposal from three geomorphosites in Rome 1298 (Italy). Quaestiones Geographicae 36(3):21-36

1299 Porta J, Poch, RM, López-Acevedo, M (2019) Edafología: uso y protección de suelos. $4^{\text {a }}$ $1300 \quad$ Edición. Ediciones Mundi-Prensa, 603 p

1301 Portal C, Kerguillec R (2018) The shape of a city: Geomorphological landscapes, abiotic 1302 urban environment, and geoheritage in the western world: the example of parks and 1303 gardens. Geoheritage 10(1):67-78

1304 Reverchon F, Ortega-Larrocea MDP, Pérez-Moreno J, Peña-Ramírez VM, Siebe C (2010) 1305 Changes in community structure of ectomycorrhizal fungi associated with Pinus 1306 montezumae across a volcanic soil chronosequence at Sierra Chichinautzin, Mexico. 1307 Can J Forest Res 40(6):1165-1174.

1308 Reynard E, Pica A, Coratza P (2017) Urban geomorphological heritage. An overview. 1309 Quaestiones Geographicae 36(3):7-20. doi: 10.1515/quageo-2017-0022

1310 Rivera D (1945) Requisitos para la organización del pedregal. Accessed from a link on the $1311 \quad$ Wikipedia webpage titled « Jardines del Pedregal ».

1312 Rodrigues ML, Machado CR., Freire E (2011) Geotourism routes in urban areas: a 1313 preliminary approach to the Lisbon geoheritage survey. GeoJ Tour Geosites 8(2):281$1314 \quad 294$ 
1315 Rzedowski J (1954) Vegetación del Pedregal de San Ángel (Distrito Federal, México).

1316 Anales Escuela Nacional Ciencias Biológicas, Instituto Politécnico Nacional 8:59-129

1317 Salas Portugal A (2006) Morada de lava. Universidad Nacional Autónoma de Mexico, $1318 \quad$ Mexico City, $204 \mathrm{p}$

1319 Sanders WT, Parsons JR, Santley RS (1979) The Basin of Mexico: Ecological Processes in 1320 the Evolution of a Civilization. Academic Press, New York, $561 \mathrm{p}$

1321 Schmitter E (1953) Investigación petrológica en las lavas del pedregal de San Angel. 1322 Congreso Científico Mexicano, Memorias 3 :218-237

1323 Schteingart M (1989) The environmental problems associated with urban development in 1324 Mexico City. Environ Urbanization 1(1):40-50

1325 Self S, Keszthelyi L, Thordarson T (1998). The importance of pāhoehoe. Annual Review of 1326 Earth and Planetary Sciences 26(1): 81-110

1327 SEREPSA (Secretaría Ejecutiva de la Reserva Ecológica El Pedregal de San Ángel) (2008) 1328 Manual de Procedimientos. Programa de Adopción de la Reserva Ecológica del 1329 Pedregal de San Ángel. Secretaría Ejecutiva REPSA, Coordinación de la Investigación 1330 Científica, Universidad Nacional Autónoma de Mexico, Mexico City, 108 p

1331 Siebe C (2000) Age and archaeological implications of Xitle volcano, southwestern Basin of 1332 Mexico-City. J Volcanol Geotherm Res 104(1-4):45-64. doi: 10.1016/S0377$1333 \quad 0273(00) 00199-2$

1334 Siebe C, Rodríguez-Lara V, Schaaf P, Abrams M (2004) Radiocarbon ages of Holocene 1335 Pelado, Guespalapa, and Chichinautzin scoria cones, south of Mexico City: 1336 implications for archaeology and future hazards. Bull Volcanol 66(3):203-225

1337 Siebe C, Arana-Salinas L, Abrams M (2005) Geology and radiocarbon ages of Tláloc, 1338 Tlacotenco, Cuauhtzin, Hijo del Cuauhtzin, Teuhtli, and Ocusacayo monogenetic 
volcanoes in the central part of the Sierra del Chichinautzin, México. J Volcanol

$1340 \quad$ Geotherm Res 141:225-243. doi: 10.1016/j.jvolgeores.2004.10.009

1341 Siebe C, Mendoza-Hernández PE, Juárez-Orozco S, Vázquez-Selem L, Cram-Heydrich S

1342 (2016) Consecuencias de la actividad volcánica del Xitle y el disturbio antrópico sobre

1343 las propiedades del suelo y la diversidad vegetal del Parque Ecológico de la Ciudad de

1344 México en el Ajusco medio. In: Comisión Nacional para el Conocimiento y Uso de la

1345 Biodiversidad (conabio) y Secretaría del Medio Ambiente del Distrito Federal

1346 (sedema). La biodiversidad en la Ciudad de México. Conabio/Sedema, Mexico City

1347 Siebe C, Macías JL (2006) Volcanic hazards in the Mexico City metropolitan area from

1348 eruptions at Popocatépetl, Nevado de Toluca, and Jocotitlán stratovolcanoes and

1349 monogenetic scoria cones in the Sierra Chichinautzin Volcanic Field. Special Papers-

$1350 \quad$ Geol Soc Am 402:253

1351 Siebe C, Rodríguez-Lara V, Schaaf P, Abrams M (2004) Radiocarbon ages of Holocene

1352 Pelado, Guespalapa, and Chichinautzin scoria cones, south of Mexico City:

1353 implications for archeology and future hazards. Bull Volcanol 66:203-225.

1354 doi:10.1007/s00445-003-0304-z

1355 Singh SK, Reinoso E, Arroyo D, Ordaz M, Cruz-Atienza V, Pérez-Campos X, et al (2018)

1356 Deadly intraslab Mexico earthquake of 19 September 2017 (M w 7.1): Ground motion

1357 and damage pattern in Mexico City. Seismological Research Letters 89(6):2193-2203

1358 Solleiro-Rebolledo E, Straubinger M, Terhorst B, Sedov S, Ibarra G, Sánchez-Alaniz JI, 1359 Marmolejo E (2016) Paleosols beneath a lava flow in the southern basin of Mexico:

1360 The effect of heat on the paleopedological record. Catena 137:622-634 
1361 Straub SM, LaGatta AB, Martin-Del Pozzo AL, Langmuir CH (2008) Evidence from high-

1362 Ni olivines for a hybridized peridotite/pyroxenite source for orogenic andesites from

1363 the central Mexican Volcanic Belt. Geochemistry Geophysics Geosystems 9(3):1-33

1364 Ticar J, Komac B, Zorn M, Ferk M, Hrvatin M (2017) From urban geodiversity to

1365 geoheritage: the case of Ljubljana (Slovenia). Quaestiones Geographicae 36(3):37-50

1366 Urrutia-Fucugauchi J, Goguitchaichvili A, Pérez-Cruz L, Morales J (2016) Archaeomagnetic

1367 dating of the eruption of Xitle Volcano, Basin of Mexico: Implications for the

1368 mesoamerican centers of Cuicuilco and Teotihuacan. Arqueología Iberoamericana

$1369 \quad 30: 23-29$

1370 Van den Berg AE, Maas J, Verheij RA, Groenewegen PP (2010) Green space as a buffer 1371 between stressful life events and health. Social Science \& Medicine 70(8):1203-1210

1372 Vereb V, van Wyk de Vries B, Guilbaud MN, Karatson D (2020) The urban geoheritage of

1373 Clermont-Ferrand : from inventory to management. Quaestiones Geographiceae, vol.

1374 39(3):5-31; doi: 10.2478/quageo-2020-0020

1375 Waitz P, Wittich E (1910) Tubos de explosión en el Pedregal de San Angel. Boletín de la $1376 \quad$ Sociedad Geológica Mexicana 7:169-186

1377 Walker GPL (1993) Basaltic-volcano systems: Geological Society, London, Special

$1378 \quad$ Publications 76(1):3-38

1379 Walker GPL (2009) The endogenous growth of pahoehoe lava lobes and morphology of lava1380 rise edges. In : Thordarson T et al (Eds) Studies in Volcanology: The Legacy of George $1381 \quad$ Walker, Spec Publ IAVCEI 2:17-32

1382 Wittich E (1919) Los fenómenos microvolcánicos en el pedregal de San Ángel: Memorias 1383 de la Sociedad Científica Antonio Alzate. México 38:101-120 
1384 Wood CA (1980) Morphometric analysis of cinder cone degradation. Journal of Volcanology 1385 and Geothermal Research 8(2-4):137-160

1386 WRB IUSS Working Group (2015) Base referencial mundial del recurso suelo 2014, 1387 Actualización 2015. Sistema internacional de clasificación de suelos. Informes sobre 1388 recursos mundiales de suelos 106. Food and Agriculture Organization of the United $1389 \quad$ Nations, Roma

1390 Zambrano L, Cano-Santana Z, Wegier A, Arroyo-Lambaer D, Zúñiga-Vega JJ, Suárez A, et 1391 al (2019) Evaluating socio-ecological interactions for the management of protected 1392 urban green spaces. Frontiers in Environmental Science 7:144

1393 Zambrano L, Rodríguez Palacios S, Pérez Escobedo M, Gil-Alarcón G, Camarena P, Lot A 1394 (2016) La Reserva Ecológica del Pedregal de San Ángel: Atlas de Riesgos. Mexico 1395 City, Mexico. Universidad Nacional Autónoma de México, Mexico City

1396 
1397 